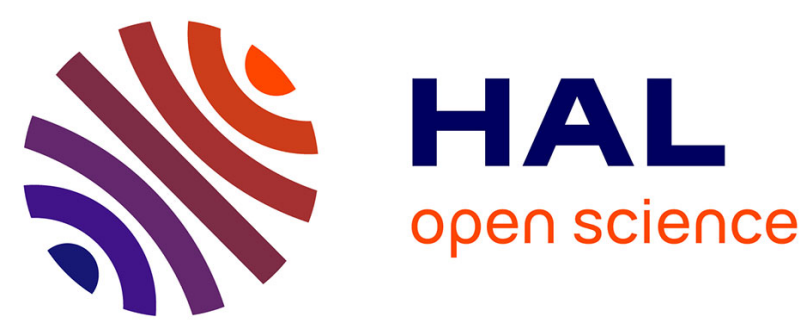

\title{
In between the market and public health insurance: a place for occupational welfare in Europe?
}

Thomas Houssoy, Marion del Sol, Philippe Martin

\section{To cite this version:}

Thomas Houssoy, Marion del Sol, Philippe Martin. In between the market and public health insurance: a place for occupational welfare in Europe?. Benoit C., Del Sol M., Martin P. (eds). Private Health Insurance and the European Union, Palgrave Macmillan, pp.281-338, 2020, 978-3-030-54354-9. 10.1007/978-3-030-54355-6_10. hal-02918413

\section{HAL Id: hal-02918413 \\ https://hal.science/hal-02918413}

Submitted on 20 Aug 2020

HAL is a multi-disciplinary open access archive for the deposit and dissemination of scientific research documents, whether they are published or not. The documents may come from teaching and research institutions in France or abroad, or from public or private research centers.
L'archive ouverte pluridisciplinaire HAL, est destinée au dépôt et à la diffusion de documents scientifiques de niveau recherche, publiés ou non, émanant des établissements d'enseignement et de recherche français ou étrangers, des laboratoires publics ou privés. 


\title{
In between the market and public health insurance: a place for occupational welfare in Europe?
}

Thomas Houssoy, Clersé (UMR CNRS 8019), Université de Lille

Marion Del Sol, IODE (UMR CNRS 6262), Univ Rennes

Philippe Martin, COMPTRASEC (UMR CNRS 5114), Université de Bordeaux, CNRS

\begin{abstract}
There is a growing body of studies emphasising the multi-pillar configuration of protection against social risk in Europe, particularly in pension reform. In this chapter, we try to expand on this literature to find applicability beyond the sole case of pensions by looking at the case of occupational health insurance in France. In order to do so, we present a restatement of the pillar/provision perspective in order to apply it to a broader range of cases. We argue it is a powerful analytical tool provided it is complemented with a (non-exhaustive) list of perspectives widely used in studies on social policy and does not blunder into the pitfall of functionalism. The chapter focuses on crossing the pillar perspective with a finance and also a regime perspective. Following the seminal intuition of $R$. Titmuss, an important result yielded is that the overall structure of resources distribution of the whole welfare system can become highly anti-redistributive once occupational schemes and fiscal incentives are included in the analysis.
\end{abstract}

\section{Introduction}

There are several approaches in academic literature to describe national Welfare State models. The most common is the scheme-based approach, but economists also employ the insurance-based approach ${ }^{1}$, while some projects are based on the notion of welfare mix, involving the combination of different spheres - i.e. the State, the market, the family and the sphere of "voluntary associations" - in the provision of social services. This latter approach can be linked with the multiple-pillar approach used in the field of retirement pensions. This makes it possible to identify the respective places of public-based schemes (pillar 1), professional schemes operating on a capitalisation basis (pillar 2) and individual voluntary retirement savings plans acting as life annuities (pillar 3). With regard to the growing role of professional pensions (pillar 2), the work on occupational welfare, which places the emphasis on the benefits and services received by employees on the basis of the employment relationship, constitutes a sound and frequent tool for the analysis of multi-pillarisation processes (Pavolini and SeeleibKaiser 2018). This makes it possible to how interractions and balance between pillars are builtup over. It also enables consideration of the segmentation of financing and of the public-private mix expressed to satisfy the social need for retirement cover.

As shown by all of the contributions to this book, the public-private mix is an issue that also affects national health insurance systems. Indeed, in numerous European countries, access to care is achieved by means of (compulsory) public health insurance combined with depending on a set of arrangements that vary from one national system to another - work-

\footnotetext{
${ }^{1}$ In this case, the Welfare State is designed to be one broad insurance policy against social risks, and the systems can be described by the manner in which they distribute public cover (more or less broad and universal), but also by the place granted to private insurance and a market to cover certain risks.
} 
related and individually contracted private insurance. Like the retirement risk, formulas based on occupational welfare are consequently present in the field of health risk. Within the European Union, moreover, they are relatively well developed. There are, however, significant differences from one country to another, as the proportion of the population covered by private insurance varies considerably ${ }^{2}$, and the distribution between group cover and individual cover is itself variable: group policies are much more common than individual policies (between $80 \%$ and $100 \%$ of the private insurance market) in the countries of eastern Europe and Scandinavia; they are in the majority in the United Kingdom, Belgium and the Netherlands (between 65 and $75 \%$ ); they are less developed in other countries like Italy, Austria, Germany and Ireland (between 13\% and 42\%) (Sagan and Thomson 2016). Although individual policies still have a slight majority on the private insurance market (52\% of contributions paid in 2018) in France, the volume of group policies is rising sharply; the trend could therefore reverse (DREES 2019). However, it was mainly in the area of retirement pensions that we saw in Europe, in the early 2000 s, major reforms consisting of systematically mobilising private insurance policies and, by extension, the market mechanisms to complement reduced public pensions. In these reforms, the professional cover was particularly activated by the set of tax incentives, as they make it possible to cover a large proportion of the population immediately in conditions that are favourable for employees due to the employer contribution. It should also be noted that "pillarisation" is not organised in the same way for pensions as for health cover. In the latter case, the distribution between public and private insurance depends on more complex factors: in a single country, the public cover can be very strong for some pathologies and more residual for other types of care, opening different options for private insurance. ${ }^{3}$

The desire to use occupational welfare literature to analyse health insurance is therefore far from straightforward. Furthermore, it is an analytical framework rarely used in this field. However, the comparative analysis of health insurance systems, as this chapter intends to show, would benefit from using these works. They make it possible to examine the systemic transformations that the mobilisation of cover of professional origins can bring or cause, especially with regard to access to care and in terms of solidarity. More specifically, it seems to us that placing the emphasis on the "professional pillar" in the field of health cover makes it possible to open up a perspective that considerably enhances the terms of the analysis. This is not (or not only) a matter of helping to provide guidance for the privatisation or commodification processes; it is about considering the bridges or alternatives that the mobilisation, or even instrumentalisation, of professional cover can build between national solidarity (public system) and that, more rarely specified, prevailing on the health insurance market.

The first subjects to be discussed, from a theoretical perspective, will be the pillar concept and the question of the place of occupational welfare (1). Then, a case of instrumentalisation of the "professional pillar" by the public policies will be up for discussion. There will first be a diachronic interpretation of the French case, which appears quite singular to the point of being an interesting analysis laboratory (2). In fact, a law of 14 June 2013 requires private sector employers to provide their salaried staff with complementary health cover and to

\footnotetext{
${ }^{2}$ It is particularly high in those countries that leave it to the insurance market to cover the co-payment factor, i.e. that part of the care not reimbursed by compulsory public health insurance. That is the case in France, where over $95 \%$ of the population is now covered by complementary private insurance, and in Slovenia, where the coverage rate is $84 \%$. The Netherlands, Austria, Belgium and Ireland also have a high coverage rate (Sagan and Thomson 2016).

${ }^{3}$ In France, for example, the care required by long-term disorders is covered by the Social Security, although responsibility for other pathologies is shared by Social Security and private insurance.
} 
contribute at least half of the funding. This change of trajectory gives an unprecedented place to group health insurance, between public health insurance and individual private insurance, as the legislature has institutionalised the role of professional cover. This policy option, previously unheard of in Europe, will give rise to a critical analysis of the distribution of resources aimed at satisfying social needs (in this case, access to healthcare) and the effects of the segmentation in terms of inequalities and the overall solidarity of the system (3). Finally, a period of reflection will provide an opportunity to discuss the possibilities for collective bargaining to build solidarity in a trading environment (4). Indeed, contemporary versions of occupational welfare never fail to remind us that it is important not to "underestimate the role of the trade unions and the collective aspect of professional relationships in the negotiation of social protection programmes" (Natali et al. 2018).

\section{The growing importance of occupational welfare in Europe as a "pillar » of social protection}

One can argue that the French health insurance system tends to take the form of a "pillar-based » architecture: its main configuration increasingly articulates a nationwide public scheme with occupational complementary health insurance plans set up at company or at sector level. This description may become even more relevant as supercomplementary health insurance plans have played a bigger role since occupational health insurance $(\mathrm{OHI})$ schemes became mandatory: 2.4 million people are estimated to have taken out such a health insurance contract by 2016 to top up their complementary coverage. For most of the rest of the population, complementary health insurance remains based on the voluntary signing of individual contracts.

This description, however relevant at first sight, cannot be understood as a direct translation of the "three-pillars doctrine " commonly used to discuss or promote pension reforms (1.1.). Moreover, its limitations do not simply apply to an analysis of health insurance in France, but can be addressed to any uses of the concept of pillars for describing any particular institutional social protection configuration covering any kind of welfare requirement. We therefore offer a more generalist description centered around the idea of a pluralist welfare system (i.e. social risk needs in a given community are answered through State and non-State schemes, together forming a welfare system) and institutional complementarity (i.e. the overall outcome (or lack of) an outcome) of a given welfare system must be seen in the light of the mutually beneficial interactions of its components - in other words, the whole is not the sum of its parts).

Drawing on the conclusion that pillars are relevant, although limited to the description of the different components of a welfare system, a closer look at studies of occupational welfare schemes is of great help in refining an analysis of the new welfare system that emerged (1.2.). However marginal occupational welfare was in social policy analysis, the few studies on the subject emphasise the importance of crossing a 'provision' perspective with the questions of the general allocation of resources for welfare needs (finance perspective) with the way industrial relations actors set up occupational schemes and define the population that can access them and the solidarity they can create (regime perspective).

\subsection{The problem with the pillar perspective taken at face value}

The three-pillars perspective has become a cliché of comparative social policy study and social policy reform, most notably when applied to pension policies (e.g. Immergut et al. 2006). This depiction articulates three pillars (the public, the occupational and the individual pillars), 
each on top of the other to achieve the coverage of a given social risk. Popularized by the landmark 1994 World Bank report «Averting the Old Age Crisis », this apparently descriptive tool cannot simply be untied from a normative agenda of structural reform favouring the privatization of pension management and financing. This derives from the manner in which the public-private mix is defined as a functional distribution of roles. The «three-pillar doctrine » has taken many forms, but is most commonly seen as a generalization of a national case, that of Switzerland, by an epistemic community of life insurers and pension consultants during the 1970s and early 1980s (Leimgruber 2012). Yet, the seminal World Bank report (1994) does not exclusively attribute an occupational character to the mandatory privately managed second pillar, nor a personal character to the voluntary top-up third pillar, as usually associated with the Swiss/classical three-pillar model. However, this report contains the most explicit exposition of the underlying common normative project any version of this model carries: an optimal pension scheme must exclusively distribute its redistributive function to a public scheme and its savings function to private schemes (ibid 1994, p. 15) ${ }^{4}$.

This is a conception of the distribution of roles between public and private that is in phase with the then-prevailing New-keynesian influence and the (American) intellectual background of the report's authors (ApRoberts 1996). Overall, it can be summed up by two tenets. Firstly, it supposed that the market remains the optimal determination mechanism of resource allocation and employment, and the State's intervention must be limited to redistribution and the correction of market failures (Bönker 2005, pp. 83-86). This functionalist perspective results in the definition of the first pillar, a public scheme mostly dedicated to providing some form of minimum benefits that does not rely on market outcomes ${ }^{5}$, and the definition of the second pillar as a mandatory and State-regulated funded scheme in order to obtain a large coverage and prevent undersavings ${ }^{6}$. Secondly, it supposed that savings, through the insurance technique, are the «natural » form of social protection (Ewald 1986, quoted in Ramaux 2007, pp. 22-25). This tenet is the driving force of the «three-pillar doctrine » as a privatization tool and derives from the statement that actuarial neutrality, cornerstone of the private insurance technique and intertemporal optimal savings management, "should avoid some of the economic and political distortions to which the public pillar is prone » (World Bank 1994, p. 16). Such a narrow definition of social protection commands the scope of the privately managed pillars and makes it the dominant variable of the « three-pillar » architecture.

We can derive that the rejection of any a priori functional distribution of role between " pillars » is a prerequisite for establishing the notion of pillar as a relevant descriptive tool for identifying and studying any form of welfare system as a pluralist institutional arrangement (e.g. Johnson 1999; Powell 2007a). We argue, in a similar manner to our study of the coherency of the "three-pillar doctrine », that understanding a given system of schemes empirically requires not simply describing each element, but also identifying the state of institutional complementarity (Amable 2004; Aoki 2001; Deeg 2007) between each of them. Institutional complementarity can be defined as the state where " the co-existence (within a given system) of two or more institutions [here, health insurance schemes] mutually enhances the performance contribution of each individual institution »(Deeg 2007, p. 611). Drawing on Powell's

\footnotetext{
${ }^{4}$ One made mandatory and tightly regulated by the State, and the other made voluntary and mostly under the full sway of classical insurance techniques and financial markets.

${ }^{5}$ In relation to this, the 1994 report notices that « [this first] pillar has the unique ability [...] to coinsure against long spells of low investment returns, recession, inflation, and private market failures » (ibid. 1994, p. 16). It points at the way the State intervenes against the overall major failure of the market when its role is to honour long-term commitments: by socializing the cost of its fundamental inability to provide long-term and secure yields. ${ }^{6}$ The necessity of such State's intervention is framed as a counterbalance to either a high individual temporal discounting from the subscribers or as a limited access to the insurance market due to information asymetries.
} 
extensive literature review (Powell 2007b, p. 4) of past welfare pluralism ${ }^{7}$ studies, there would be a descriptive and prescriptive use of such a perspective. Although we do not adhere to such terminology, our use of the concept of institutional complementarity to describe a welfare system would fall in the category of "prescriptive » analysis. It draws from sharing the fundamental assumption (and observations in our case studies, as we will argue) that a welfare mix is not simply about the additive cumulation of all its components, that variations in the welfare mix over time cannot be considered a «mere rearranging of furniture in the drawingroom » (Mishra 1990, p. 112, quoted in Powell 2007a, p.4).

Using this framework on the French case in health insurance, the development of occupational health insurance must be understood as part of an overall reconfiguration of the relations between the national health insurance (NHI) scheme and the private health insurance market. Additionally, we can analyze how it is linked with changes in policy paradigm (Amable and Palombarini 2009). Indeed, as we will argue, the French case illustrates how a shift in the role of private insurance and the development of company- and sector-based complementary schemes is not so much a direct application of the " three-pillars doctrine » as a pragmatic and unplanned response to a shift in paradigm, here in health policy. Similarities with the case of pensions must, therefore, be understood as deriving from a similar reconfiguration favouring private management within the peculiarities of health insurance institutions and debates.

\subsection{The complexification of European welfare systems in the early 21 st century and the development of occupational welfare}

Although wide variations exist in the distribution of importance of the State intervention relative to non-State interventions across social risks and countries in Europe, many studies of social policy focus on the role of the State in finance, provision or both. Such focus cannot be considered wrong-minded as many European welfare systems are unequivocially welfare state in the sense that private actors, for-profit or not, and alternative forms of social order to the State (Streeck and Schmitter 1985) are usually either dominated by State intervention or clearly marginalized when appraised on a quantitative basis (most notably in financial terms). However, as we argued, the non-additive nature of welfare systems, once we account for all its different components, gives grounds for assuming the complexities emerging from the interaction between components are an integral part of any analysis. Many recent proposals of pluralist analysis of social policies and social protection (Ebbinghaus 2011a; Goodin and Rein 2001; Powell 2007b) offers hints on how to analyze such systems. Overall, welfare systems are institutional arrangements that do not rest on consistent categories encompassing dimensions of governance, finance, benefits logics, etc. Henceforth, there is little to no relevancy in unidimensional descriptions and typologies. For the sake of clarity, we limit ourselves to a twodimensional reading of the situation, allowing for discussions on the interaction of multiple non-coincidental dimensions.

Drawing on Ebbinghaus (2011a), a welfare mix for a given social policy can be described by answering five questions for each of its components : (i) who is covered, (ii) what kind of benefits are served, (iii) who pays, (iv) who provides and (v) who governs, decides and manages. Adopting the typology of pillars, and therefore a provision perspective (i.e. focusing on question 4), allows for a practical description of the main configuration a welfare system can take. However, it hardly helps to established clear links with the other four questions

\footnotetext{
${ }^{7}$ The term «mixed economy of welfare » is also used widely, including by Martin Powell himself. We follow Johnston (1999, p. 22) in considering both terms «identical in meaning and [...] therefore can be used interchangeably » (Powell 2007b, p. 2).
} 
considered alone. Using the French health insurance system as an example, the NHI scheme can easily be identified as the public pillar, but its evolution over time shows great shifts in the content of all of the other axes. An oversimplified presentation of this evolution would depict it as a social insurance that, between 1945 and today, moved from covering most private wageearners to being close to a universal scheme, from serving mostly as 'sick pay' to almost exclusively insuring health consumption expenditure, from being financed almost exclusively by social contributions to being mostly financed by taxes, and from self-administration by trade unions and employers associations to de facto State administration.

A closer look at the occupational pillar might help select proper second dimensions for analysis. Occupational welfare has a long history despite being rarely put forward in social policy analysis during the pre-2000s period (Rein 1982; Rein and Wadensjö 1998; Shalev 1996). Coined by Richard Titmuss in his seminal lecture, The Social Division of Welfare (1958), it referred first to a vast and vaguely defined array of « benefits received by an employee through or as a result of his employment over and beyond the public benefits such as national insurance » (Sinfield 1978, p. 130). However, such a definition is ill-fitted to apprehend its contribution to the welfare mix as it hardly differentiates between simple company perks (such as company cars) and social benefits (Goodin and Rein 2001, pp. 773-774). Overall, its most fruitful contribution, both descriptively and analytically, lies in the original formulation of Richard Titmuss as a tool for understanding the social division of welfare. As a descriptive tool, looking at public welfare alone (i.e. «the » welfare state as commonly understood) is not enough; occupational and fiscal welfare must be added to the analysis ${ }^{8}$ (e.g. Hacker 2002 and 2004; Howard 1997) in order to identify all socially-determined tools for financing or providing services and goods fulfilling welfare needs ${ }^{9}$. As an analytical tool, it enables the examination of the full structure of resource allocation for welfare needs, most notably to highlight the antiredistributive outcomes of the welfare system that an exclusive focus on the public welfare too easily hides.

Although it had an Anglo-Saxon focus, probably due to the substantial increase in occupational health insurance in the United States and occupational pensions in the United Kingdom (e.g. Cutler and Waine 2001), occupational welfare has always been a significant but often neglected part of the European welfare systems (Farnsworth 2004; Rein 1996), including France. Such a shortcoming in the study of (mostly West \& Northern) European welfare states is progressively addressed by an expanding literature since the mid-2000s (Ebbinghaus 2011b; Greve 2007; Natali et al. 2018). This literature mostly stems from the rising importance of occupational pensions in all types of European welfare state (e.g. De Deken 2018; Naczyk 2013; Trampusch 2007), but expanded to other kinds of social risk (e.g. Greve 2018; Järvi and Kuivalainen 2013; Seeleib-Kaiser and Fleckenstein 2009; Yerkes and Tijdens 2010). While the first trend focused on defining occupational welfare and assessing its scope and distributional outcomes, this second trend tends to focus on the institutional set-ups and actors involved, particularly those in industrial relations.

Overall, two strands exist in this segment of the literature, representing opposite theses on the outcomes of the implications of actors in industrial relations, particularly trade unions: a solidaristic-collectivization thesis (Johnston et al. 2011; Trampusch 2009) and an egoisticdualization thesis (Häusermann 2010; Palier and Thelen 2010). The solidaristic or

\footnotetext{
${ }^{8}$ It refers to all forms of deductions, rebates or fiscal measures the State used to promote and orient private initiatives.

${ }^{9}$ The most common example related to our case study is that occupational pensions or health insurance schemes contributions or benefits are often deducted from the calculation of taxes.
} 
collectivization thesis argues that trade unions might push for negotiated occupational welfare in order to cope with a lack or retreat of the public welfare state (Yerkes and Tijdens 2010) but also to maintain or gain power and position and extend their constituency (Naczyk and SeeleibKaiser 2015). According to this thesis, this results in the development of solidaristic occupational welfare. Following prior studies emphasising important intra-labour divergent preferences in social policy and possibilities of cross-class alliances (Hall and Soskice 2001; Mares 2003; Swenson 1991; Thelen 1993), the egoistic or dualization thesis posits that trade unions in core sectors, facing post-industrialism and decentralization of collective bargaining, shifted from promoting encompassing social improvements nationwide to local agreements with management to protect their position on the labour market. According to this thesis, this results in the development of a welfare dualism where " insiders » benefit from generous occupational welfare schemes, leaving the « outsiders » facing little to no access to such a form of social protection.

This dual interpretation of the concept of occupational welfare helps us to highlight two fruitful forms of interactions with the provision perspective: a finance perspective can clarify how the configuration of welfare resources allocation is organized among the different forms of health insurance provision (section 3) and a regime perspective focuses on the reconfiguration of the forms of solidarity prompted by the emergence of OHI schemes in France (section 4).

\section{The activation of an aspect of welfare for a new purpose: the French case of occupational health insurance}

Occupational welfare is a form of social protection that is not only ancient but never truly disappeared or became marginalized when the modern French welfare state, centred around public welfare, was instituted in 1945. However, the case of OHI shows that it neither grew from the immediate post-war period to become an important part of the French health insurance system, nor was it a component that received much attention from the public authorities until a later period starting in the 1980s. On the contrary, a historical perspective on $\mathrm{OHI}$ in France shows that it emerged recently when the French Government chose to " activate " this aspect of welfare as a tool for a larger renewal of public health policy. Even within this shorter period, the important role OHI plays nowadays is not so much the results of a planned process, but rather the results of accidents and opportunities.

It follows that the history of $\mathrm{OHI}$ in France can be roughly understood as a succession of two periods. The first and longest one spans from the early industrialization to the 1980s (2.1.). During this period, OHI is firmly a part of the social policy of the firm (Rein 1982). Everything from setting it up to the forms it took resulted from the work of industrial relations actors. Public authorities, on the other hand, were mostly acting through the expansion of NHI. From the end of the 1980s onwards, changes in the political economy of the French health insurance system led to an increasing role played by private health insurance, under the guidance of the French Government (2.2.). During this period, it was the overall goal of increasing access to complementary health insurance through ever-stricter regulation that was the main driver of institutional change. The 2004 Douste-Blazy Law is the tipping point when $\mathrm{OHI}$ is explicitly seized by public authorities as a tool for public health policy at large. 


\subsection{A constitutive part of the social protection of French private wage-earners since the inception of a national health insurance}

Like many European welfare states (Farnsworth 2012), the roots of the modern French welfare state are to be found in the development of occupational welfare in the new industrial urban centres that emerged during the second half of the 19th century and early 20th century (Castel 2002; Hatzfeld 1971). Up to the interwar period, these health insurance schemes remained concentrated on an ever-growing share of civil servants and industrial workers in the population. By the late 1920s, this constellation of occupational schemes for State employees, train drivers, coal miners, etc. covered $56 \%$ of the total population (Dreyfus 2009). The first attempt at creating a mandatory health insurance coverage took place under the provisions set up by the law of $1928^{10}$, modified on July 1st, 1930. Although it cannot be described as making OHI schemes mandatory, it was clearly based on the experiences these schemes provided. Moreover, while setting up a national framework, the laws of 1928 and 1930 allowed preexisting occupational schemes to continue to exist and to act as substitutes for the new institutional framework. The ability of old occupational schemes to survive the progression of public welfare is one of the many compromises made for setting up this mandatory health insurance scheme that determined the evolution of French social protection to the present day.

With the creation of the Sécurité sociale (literally, «Social security») in $1945^{11}$, the social policy of a firm was now an element of complementary rather than basic social protection. The period 1945-1946 corresponds to a phase of increasing employees' power, directly or through their representatives. Work councils were instituted ${ }^{12}$ and given an important role in setting up and managing the firm's social policy, contributing to an initial movement away from traditional paternalism. By 1946, the new social protection architecture enacted the existence of a second complementary tier where firms play a role and established a new kind of insurance institution for collective social risks coverage, set up through collective bargaining by trade unions and employers and administered by them ${ }^{13}$. The decision to set up any occupational welfare scheme for the benefit of the employees and the determination of the employers' participation have, since then, been left either to the discretionary decision of the employer or to collective bargaining, at either company or sector level ${ }^{14}$. In these early days of the modern French welfare state, firms' social policies and initiatives are neither significantly regulated nor instrumentalized by the national government as a prolongation of public social policies. One exception is the case of complementary occupational pensions which emerged under highly peculiar circumstances and forms (Friot 2012, pp.93-122), leading to the establishment of a nationwide quasi-public scheme on top of the basic public scheme by the 1970s.

Collective bargaining at sector level was crucial for the development of the coverage of many social risks. However, OHI was and remained a matter of collective bargaining at company level (Kerleau 2009, p. 17). This was the case since the early days of the modern

\footnotetext{
${ }^{10}$ Law of April $5^{\text {th }}, 1928$ on social insurance.

${ }^{11}$ Ordinance of October $4^{\text {th }}, 1945$ on the organisation of Social Security \& Ordinance of October 19th, 1945 on the social insurances for insurees in non-agriculutral occupations.

${ }^{12}$ Ordinance of Feburary $22^{\text {nd }}, 1945$ instituting companies' councils (in French, comités d'entreprise, which were roughly what is commonly designated as workers'councils). The comités d'entreprise were replaced by the comités sociaux et économiques (social and economic councils) by January $1^{\text {st }}, 2018$.

${ }^{13}$ Ordinance of June $8^{\text {th }}, 1946$ on the common provisions for complementary welfare for employees (in French, régimes complémentaires des salariés).

${ }^{14} \mathrm{~A}$ third procedure consists of setting up occupational schemes by directly consulting the employees by referendum. However, this procedure is rarely used.
} 
French welfare state, as some of the pre-existing occupational schemes survived by transiting to company-based mutual funds ${ }^{15}$, sometimes under the supervision of the workers' council (Kerleau et al. 2008, p. 19). In any case, the initiative is in the hands of private actors. Within the firm, social protection is part of a large array of elements forming the remuneration of the employees, from perks to social advantages. No employer has any mandate to set up an OHI scheme but it can be used as a tool in the larger trade-offs constituting a firm's wage policy. Most of the second half of the 20th century is a period of development of social advantages earned through employment in a firm, but it is excessive to consider these dynamics as a process of institutionalization of occupational welfare in France (contra Kerleau et al. 2008, p. iii). On one hand, setting up such welfare schemes remained highly discretionary and practices were highly differentiated across companies. On the other hand, as an element of trade-off and bargaining on wages, the forms and extent these occupational health schemes took were highly dependent on the local compromises reached between the industrial actors involved.

Public authorities first ventured into making OHI schemes a tool of public policies in the 1970s and 1980s, through two means: the creation of tax and social contributions exemption on one hand, and the strengthening of regulation on the other hand. The French Government first introduced tax exemptions in 1975: employees could deduct the premium they paid for health insurance from their income tax, within a limited amount, providing the occupational scheme was collective (i.e. it was made accessible to a category or all of the employees of a given company) and mandatory (i.e. all employees of a category or company had to subscribe to the scheme) (Kerleau 2009, p. 18). During the 1980s, these advantages were expanded to the benefit of the employers by deducting their financial contributions ${ }^{16}$ to any occupational schemes from both the base value for the calculations of social contributions to Social Security and other legal and national social protection schemes, and from corporate tax. The second instrument the French Government used to advance public policy goals was the new regulation introduced by the pivotal 1989 Evin Law ${ }^{17}$. The 1980s was a crucial turning point for the evolution of the private health insurance market in France (see also chapter 7). Although OHI schemes were not the focus of this reform, the 1989 Evin Law prepared the way for the increasing role private health insurance was about to play in financing health consumption and fulfilling public health goals. Many central provisions to this day, such as the prohibition of medical selection and the guarantees of coverage maintenance in unemployment, were introduced by the 1989 Evin Law. Overall, this first wave of public interventions was relatively minor for OHI schemes. Public authorities incentivized their expansion and established some protections for employees, but never intended to fully instrumentalize these schemes or orientate their contents, finance and mode of governance.

\subsection{The late development of occupational health insurance in France}

The last pivotal moment leading to the generalization of OHI in France started with the generalization of the basic NHI through the creation of the Couverture Médicale Universelle $(\mathrm{CMU})^{18}$. During the debate leading to the vote on the 1999 CMU Law, the high dependency of any beneficiary to private insurance financing forced the public authorities to include a free

\footnotetext{
${ }^{15}$ Following the Ordinance of October 19th, 1945 on the statutes of mutual funds (in French, mutualité).

${ }^{16}$ French law makes a distinction between taxes (i.e. fiscal in French) paid to the State, and social contributions (i.e. social in French) paid to Social Security and other legal and national social protection schemes. They are organized as two separate sets of mandatory contributions and are governed by different sets of rules.

${ }^{17}$ Law of December $31^{\text {st }}, 1989$ reinforcing the social guarantees provided to persons insured against certain risks.

${ }^{18}$ Literally, Universal Health Coverage. This was replaced by the Protection Universelle Médicale (PUMa, literally Universal Health Protection) by January $1^{\text {st }}, 2016$.
} 
complementary stage to this new scheme $\left(\mathrm{CMU}-\mathrm{c}^{19}\right)$. This resulted in two major modifications. The first major disjunction with the institutional path in place since 1945 was the paradigm shift in public policy from an objective of universal (basic) health insurance coverage to an objective of greater access to private complementary health insurance (Kerleau 2012). This shift in the evolution of the French health insurance system was the result of almost two decades of transformation of its political economy. However, nothing at that moment required $\mathrm{OHI}$ schemes to be detrimental to this new health policy goal. The second major disjunction with the previous institutional path is more accidental and helped push OHI schemes to play a larger role in the new health insurance system. Through an amendment of Article 21 of the 1999 CMU Law sponsored by Communist members of Parliament, two modifications of the labour law were included that truly set the stage for increasing coverage by $\mathrm{OHI}$ and for promoting collective bargaining as its main form of governance (ibid. 2012, p. 9). From 1999 onwards, the inclusion of provisions on $\mathrm{OHI}$ is required in any sectoral branch agreements for benefiting from the erga omnes clause delivered by the Ministry of Labour ${ }^{20}$. Moreover, setting up an OHI scheme must be included on the agenda of the Négociation Annuelle Obligatoire ${ }^{21}$ in each company with at least one trade union representative if such a scheme is absent at sector or company level. Although this last provision was intended to stimulate the expansion of $\mathrm{OHI}$ through company-level agreements, it did not include any mandate for concluding such agreements, only a mandate to initiate talks. Therefore, besides being accidental modifications, these provisions remained, in practice, within the domain of incentives rather than direct constraining regulation, and therefore depended on the will of industrial actors.

The 1999 CMU law opened up a short period of uncertainty concerning the tools public authorities would use to increase access to private complementary health insurance. Two laws, passed in 2003 and 2004, settled the question in favour of a combination of higher regulation on the content of health insurance contracts, special schemes directed to low-income beneficiaries and increased subsidization of OHI schemes through fiscal welfare. The 2003 Fillon Law ${ }^{22}$ drastically reformed the French pension system and was an opportunity to promote funded occupational pensions by reforming the logics and use of fiscal welfare (Kerleau et al. 2008 , p. 33). It did so by making conditions for accessing tax and social contributions exemptions stricter ${ }^{23}$. This resulted in introducing a new logic in the use of fiscal welfare by the French Government, since its aim was not simply to promote occupational welfare, but also to dictate its main parameters. What was at stake was "organizing and rationalizing social protection within the firm » (Kerleau 2012, p. 186, our translation). By reforming the entire apparatus of tax and social contributions advantages, fiscal welfare became a "privileged tool of public regulation of [private] social protection $»$ (Zemmour 2013, p. 53 our translation). Hence, the 2003 pension reform affected every form of occupational welfare and had the greatest impact in the case of OHI. If the role of the pension reform seems accidental, the 2004 Douste-Blazy reform ${ }^{24}$ was the moment when public authorities explicitly included OHI as a tool of public health policy. Building on the 2003 Fillion Law, it tightened the conditions for benefiting from tax and social contributions exemptions by requiring the benefits basket to

\footnotetext{
${ }^{19}$ « $\mathrm{c} »$ standing for complémentaire (complementary).

${ }^{20}$ An erga omnes clause (clause d'extension in French) allows the binding provision of a branch agreement to be extended to all companies and employees within that branch, whether a company or employee is affiliated to the signing employer associations or trade unions. For such a clause to exist, the French Minister of Labour must sign a decree.

${ }^{21}$ Literally, Mandatory Annual Barganing, introduced by the Law of November, 13th 1982 on collective bargaining and collective labour conflict resolution.

${ }^{22}$ Law of August 21 $1^{\text {st }}, 2003$ on pension reform.

${ }^{23}$ Decree of May $9^{\text {th }}, 2005$.

${ }^{24}$ Law of August 13th, 2004 on health insurance reform.
} 
abide by a legally defined standard. This standard, known as contrat solidaire et responsable ${ }^{25}$, was not limited to setting minimum levels of coverage but also aimed to promote a financial regulation built on a model of responsible, individual and rational beneficiaries within the entire French health insurance system. This goal required private health insurance not to offset the array of incentives and disincentives introduced in the NHI and therefore made insurance providers actors of the implementation of the public health policy (Batifoulier et al. 2007).

Overall, OHI schemes were instrumentalized as means to facilitate access to private insurance by preventing most individuals from being alone and powerless on the health insurance market through a form of regulated collectivization (i.e. strengthening the demandside through group purchase). To that extent, the French case of $\mathrm{OHI}$ is similar to other recent experiences of occupational welfare (e.g. Johnston et al. 2011). The new regulation that emerged in 2004 sponsored a model of occupational schemes close to a private version of social insurance. It only subsidised schemes with a mandatory subscription of employees (i.e. based on mutualization) and equal co-financing by the employers (i.e. the same cost-sharing within the whole of the employees or an objectively defined group of them). This represents the model around which $\mathrm{OHI}$ schemes are organized up to the present day. However, even though the 2003 and 2004 laws increased regulation on these schemes, public intervention remained based on incentives rather than a direct mandate up to 2013. The intermediate period, while appearing calm, showed signs that one last paradigm shift was building up. Evidence of one such sign can be found in a commentary by Jean-Marie Spaeth (2008, p. 36), former chairman of the NHI Board of Administrator, who emphasized that while industrial relations actors lost most of their grasp on the administration of the NHI by 2004, OHI was an opportunity for the renewal of their action in social protection. Moreover, the Commission Nationale de la Négociation Collective ${ }^{26}$ delivered on February 6th, 2007 to the Minister of Labour Gérard Larcher a report inviting employers associations and trade unions to reach a nationwide agreement on making OHI mandatory throughout the private sector (Kerleau 2009, p. 19). Such an agreement was reached on January $11^{\text {th }}, 2013^{27}$ and prompted a significant process of paradigm shift that lasted until 2016 and the full implementation of the mandate. First, it definitively shifted OHI schemes within the domain of public policy by abandoning the logics of incentives (Del Sol 2014). This shift, however, cannot be reduced to the mandate put on private companies to provide health insurance coverage, since public authorities also chose to drastically modify the regulation put in place in 2004. Beyond introducing a minimum employers' share of co-financing (50\%), it introduced a new standard benefits basket which set minimum and maximum benefit levels ${ }^{28}$.

\section{A political option that redefines the distribution of welfare resources}

The reconfiguration of the socialised and private financing of healthcare in France represents a political decision that has transformed the role of national and complementary health insurance. Understanding this means, in the first instance, identifying the theoretical and ideological principles of the movements towards the privatisation of healthcare systems (André et al. 2016), in particular the various strategies for competition that can be identified in the recent transformations undergone by the Bismarckian health insurance schemes (Hassenteufel and Palier 2007), and an institutional complementarity between the two major types of health insurance (3.1.). The first term enables several successive governments of different political

\footnotetext{
${ }^{25}$ Literally, solidarity-based and responsible contract. Its first parameters were set up by the Decree of September 29 th, 2005.

${ }^{26}$ Literally, National Commission on Collective Bargaining.

${ }^{27}$ Translated by the Law of June 14th, 2013 on employment security (in French, sécurisation de l'emploi).

${ }^{28}$ Decree of November 18th, 2014 and Social Security Budget Law for 2014.
} 
parties to contribute to this reconfiguration by sharing a single representation of the problems facing the French health insurance system and therefore the solutions to be employed to resolve them. The second term makes it possible to facilitate the privatisation process. On the one hand, this has involved taking into account the risk of under-consumption of healthcare and the ethical concerns that the exposure of vulnerable or seriously ill populations to private health insurance can cause. And on the other hand, the segmentation of the financing in line with the type of healthcare enables complementary health insurance organisations to focus on the financing of ambulatory or primary care, insurance for which is financially more sustainable.

However, this choice is not without impact on the solidarity in the health insurance system or on the inequalities of healthcare (3.2.). Accordingly, the key aspect of solidarity in the French health insurance system is the result of the presence of Social Security, and especially of its financing in proportion to income. Furthermore, the historic flaws in the regulation of private medicine in France generate worrying levels of inequality of access and failures to take up care, mainly for financial reasons. This is in addition to inequalities in the quality of reimbursements and in the financial cost of individual and group policies. Thus, the privatisation of the financing of ambulatory or primary care is a policy that encourages the proliferation of inequalities on the labour market and favours some socio-professional groups via group policies.

\subsection{Privatisation and segmentation of NHI coverage as a root of the development of occupational health insurance}

The development of group cover for complementary health insurance is inseparable from the reconfiguration process of the roles between Social Security and the insurance market that has occurred in France since the early 1990s (see also chapter 7). This process, presented as a "silent metamorphosis of health insurance" (Tabuteau 2010), can be summarised as a change in the distribution of private insurance financing which, while officially remaining complementary (i.e. provided to finance a treatment, as a supplement to Social Security financing), in general terms takes a more complementary role (i.e. becomes the principal financial sponsor). In France, this takes the form of a slow but effective withdrawal of the Social Security financing of so-called ambulatory or primary care, i.e. everything ranging from a visit to the GP, to dental or eye care. In addition to the shortcomings in the regulation of private medicine costs, the main driver of this reconfiguration is the adoption of a cost containment policy for public healthcare expenditure. The change of policy generally originates from the new imperatives of European integration, whether in regard to the question of containing public expenditure as a result of the Maastricht Treaty and the introduction of the single currency (Palier 2017, pp. 55-56), or the question of competitiveness and the containment of labour costs (Barbier and Théret 2009, pp. 32-34). In practice, several estimates come together to show that chronic and hospital care are financed by Social Security up to approximately $90 \%$, while the financing of ambulatory or primary care for the core population has been reduced and could fall to just over 50\% (DG Trésor 2015; HCAAM 2011, p. 77, 2013, p. 203; Legal et al. 2009). Two aspects of this process interest us directly in the understanding of the "pillarisation" of the architecture of French health insurance as a system. On the one hand, the coherent existence of this system is based on the adoption of a theoretical and ideological underpinning by successive governments that has enabled them, without common party affiliation or overall unique reform, but by successive and incremental modifications, to justify and introduce the privatisation of healthcare financing. On the other hand, the segmentation of the population and of the financing of healthcare generated by this theoretical and ideological underpinning is able to produce a form of institutional complementarity favouring the functioning of the health 
insurance market by removing the least solvent treatments and sectors of the public from its scope.

Such a description closely matches what can be described as a "social liberal" or "New Keynesian" configuration, opposed to the social state logic that was prevalent in France for a long time after 1945 (Palier 2010; Ramaux 2012, pp. 173-178). This configuration can be described as a shifting of the role of government intervention towards a functional distribution of the roles fundamentally similar to that identified in the three-pillar pension model: public spending or regulation effectively play a role that is functionally equivalent to a correction of "market failures". If we take this parallelism seriously, it should be emphasised that the types of failure generally highlighted by a large part of the health insurance economics are different from those in the case of pensions. First of all, the market failure usually put forward is not so much the result of an under-allocation (for retirement pensions, under-savings) but rather of an excess caused by the presence of risks of moral hazard on both sides of the exchange of medical goods or services: over-consumption of care goods and services (Pauly 1968) or physicianinduced demand (Evans 1974). The second point is that both full insurance (i.e. no direct personal contributions in healthcare consumption) and the diversity of French-style insurance models (Dormont et al. 2014; Franc 2017) are seen as sub-optimal. The gradual fragmentation of the health insurance system, to the point of now describing access to complementary cover as a "constellation" of measures (Del Sol 2014, p. 171), supports the idea that this institutional change cannot be reduced to the unilateral application of a program dictated by an economicsbased vision. It should also be borne in mind that the concept of moral hazard gradually took on the character of a theoretical and empirical failure, to the point where the financial contribution of the patient could be regarded as harmful to society, especially when it completely prevents access to treatment for the most serious illnesses (Nyman 1999a) or does not permit access to the necessary treatment for the worsened state of health of the poor (Nyman 1999b).

While the analysis took a moralising turn in the face of this rather unique form of exchange, the analyses resulting from moral hazard survived in the form of "conventional wisdom" underlying the neo-liberal policies attacking the European public health insurance systems. In this context, the desire to reduce public spending on health means increasing the contribution of patients, for which the economic theory emerging from M. Pauly's seminal work supplies a scientific credibility. However, the unequal and harmful consequences for the health of the population represented by such a strategy necessarily collide with ethical challenges, which are also supported by health economics. The privatisation of healthcare financing therefore involves drawing up a list of collective priorities, which took the form of an increase in the co-payment, sparing vulnerable groups and the most expensive care (Batifoulier 2012).

It should therefore be noted that the constitution of legal, regulatory, tax and social security measures leading to the expansion of group health insurance can be interpreted as "opportunistic" measures, in the sense that they will only emerge during a broader discussion on the privatisation of healthcare financing without every really being the main subject. As discussed in the previous section, provisions favouring expansion by negotiation were made during the debates on the 1999 CMU law on universal healthcare coverage, principally intended to provide basic and complementary cover to the poorest members of society. Likewise, the principal objective of the Douste-Blazy law of 2004 was to create a coherent system creating the figure of a patient who is a market player and the manager of his/her own health capital (Batifoulier et al. 2008). As well as supplementing the policy of access to complementary cover 
for low-income households by supporting households that do not qualify for CMU-c, the social and tax benefits scheme it consolidates is above all a mechanism for expanding this type of scheme via state-approved complementary policies. The obligation to take out insurance via the company, although not incompatible with the implementation of this reform, is not necessary for the construction of the "autonomous" patient as the heart of this institutional change lies in the control and incentive mechanisms permitted by these policies.

The systemic effect of the segmentation process produced by the concentration of the financing of national health insurance on major treatments and hospitalisation creates a form of institutional complementarity favouring private health insurance for ambulatory or primary care, focused on three main dimensions. According to an element of composition, by removing expenditure related to the most serious risks, this segmentation reduces the amount of the premiums (Legal et al. 2009, p. 68) and thus reduces the risk of not using private insurance. As well as increasing access to healthcare, such a configuration makes it possible to increase the number of solvent beneficiaries on the most profitable part of the risk cover. According to an element of selection (i.e. the traditional element of adverse selection by the insurers), starting from an initial situation where a single form of cover is provided by each insurer, making "major risk" private insurance cover financially viable requires the possibility of capturing a large number of "healthy" subscribers to fund the insurance of the sick. Otherwise, the selection made possible by competition would work against such an approach. This selection can involve the insured "voting with their feet" 29 or the diversification of policies by insurers in order to capture the "healthy" population. This mechanism would tend to reduce the cover to the needs of this sub-population, thus aligning the premiums, and would influence the solvency of the insurance of chronic care by reducing the possibility of financial transfers between these two populations. Finally, according to an element of externalities, the guarantee offered by a high level of social management, of chronic care in particular, makes it possible to reduce the level of refusal of care of pathologies themselves able to cause an indirect rise in the use of "light" care. This leads to a a reduction in negative externalities in the management of diseases most often reimbursed by private insurers, including when these insurers only cover ambulatory or primary care (Dourgnon et al. 2013).

\subsection{A policy tool reinforcing the Social Division of Welfare of the French health insurance system}

When R. Titmuss (1958) proposed one way of considering social protection beyond these public measures, his main concern was to show the many ways in which the social construction of the allocation of the resources intended to meet social needs greatly favours the middle and upper classes. Two central mechanisms must be added to obtain a more relevant picture. Firstly, the private initiative and the market form the dominant mechanism of the allocation of resources beyond the democratic debate and State allocation in Europe and in France. Next, by identifying fiscal and occupational welfare, R. Titmuss also highlights their frequent association, amplifying the phenomenon of social division. His original idea could also bring to light the link between this construction and the way in which the actions and interests of social groups attempt to acquire the resources intended to meet social needs, and thus to understand how their conflicts and distribution of power between them explain the form this system takes (Sinfield 1978). Without being able to achieve this final level of analysis, we argue that the new segmentation of healthcare financing, the increased number of mechanisms to access complementary cover and the development of group cover have reinforced the social

${ }^{29}$ The "healthy" population would tend to focus on those insurers that, specialising in covering them, would be able to offer lower premiums at the cost of excluding the more seriously ill. 
division of the French health insurance system. Firstly, the privatisation of healthcare financing threatens the solidarity of the system. Adapting the Gini index to show the degree of difference between contributions and consumption per income decile, Jusot et al. (2017) show that most of the systemic solidarity is the product of national health insurance, due to its financing based on income and therefore unrelated to health needs. Conversely, complementary health insurance plays an insignificant role due to its predominantly flat-rate funding: only $10 \%$ of individual policies and 16\% of group policies between 2011 and 2013 have a rate that is based on income (Montaut 2018). Indirect forms of solidarity through funding are mobilised, especially in favour of seniors (63\% of individual policies) and families due to the free complementary cover for some (89\% of individual policies) or all children (59\% of group policies), although these have very little impact on the systemic solidarity generated by complementary insurance.

France is characterised by worrying levels of inequality in healthcare. On the face of it, we can expect that, in the event of illness, access to healthcare will be divided evenly according to socio-economic groups if it is accessible without barriers. However, an individual's declared state of health tends to improve in line with income: in 2014 , while $30.6 \%$ of the population declared themselves to be in a poor state of health ${ }^{30}$, that represents $38.9 \%$ of the population of the first income quintile (between $€ 0$ and 952) and this share decreases with each quintile to represent $22.0 \%$ of the population of the last quintile. The result is that if each beneficiary meets their healthcare needs, then the distribution of access to healthcare must be more concentrated on disadvantaged people. However, in Europe, we are seeing inequalities in access to specialist care in favour of the wealthiest groups, and these inequalities are particularly marked in France: the richest 50\% have twice as much access to specialists as the poorest $25 \%$ (Jusot 2013). This is as much the case for the annual probability of reliance on care as for the number of visits, and places France at the head of most of the ratings among the European countries, although it ranks lower for access to general practitioners. The performance of the French health system can be linked to problems with the regulation of private medicine prices: in 2017, extra fees represented $2.7 \%$ of the income of GPs $\left(26.6 \%\right.$ for Sector $\left.2^{31}\right)$ but $17.7 \%$ for specialists $(32.6 \%$ for Sector 2).

In general terms, the probability of reliance on care and the number of visits to the doctor are significantly different, all things being equal (including monitoring the state of health), between socio-economic groups, both for general refusals and by type of care (Dourgnon et al. 2012). This is easy to see with the help of descriptive statistics (Tab. 1): in 2014, refusal of care systematically decreases when an individual has complementary cover, and refusal for financial reasons is the leading cause. Thus, the process of the privatisation of the financing of routine healthcare is a factor in the potential development of healthcare inequalities, especially in France. The introduction of CMU-c can be interpreted in this way and was to some degree capable of curtailing this effect for the most disadvantaged populations, as is shown by the intermediate level of refusals of care observed among these beneficiaries. Likewise, it causes additional effects in terms of reducing the remaining amount payable by households with the Long-Term Conditions scheme (Dourgnon et al. 2013), assuming a large share of the expenditure on chronic care.

\footnotetext{
${ }^{30}$ This term refers to all of the responses to the 2014 EHIS-ESPS survey formed from a declaration on the state of health corresponding to "quite poor", "poor" and "very poor".

${ }^{31}$ Price regulation in private medicine is divided into two sectors in France. "Sector 1" concerns private practice doctors who have agreed to apply the state health service contract. "Sector 2" concerns private practice doctors who have not agreed to apply this contract and can therefore apply a free pricing system. 'Extra fees' are that part of the price of care over and above the agreement price. See Chapter \# for further details.
} 
Tab. 1 - The percentage of the population who have reported that they have foregone care in 2014, in accordance with their insurance situation

\begin{tabular}{|c|c|c|c|c|c|}
\hline \multicolumn{2}{|c|}{$\begin{array}{l}\text { Refusals or care } \\
\text { reported }\end{array}$} & $\begin{array}{l}\text { General } \\
\text { population }\end{array}$ & $\begin{array}{c}\text { Private } \\
\text { complementary }\end{array}$ & $\begin{array}{c}\text { Complementary } \\
\text { CMU }\end{array}$ & $\begin{array}{c}\text { Without } \\
\text { complementary }\end{array}$ \\
\hline \multirow{3}{*}{$\begin{array}{l}\text { By type } \\
\text { of care }\end{array}$} & $\begin{array}{l}\text { Dental } \\
\text { care }\end{array}$ & 16.8 & 15.3 & 21.7 & 40.1 \\
\hline & $\begin{array}{l}\text { Optical } \\
\text { care }\end{array}$ & 10.1 & 9.0 & 16.4 & 25.1 \\
\hline & Doctors & 5.2 & 4.4 & 6.8 & 19.6 \\
\hline \multirow{3}{*}{$\begin{array}{l}\text { By } \\
\text { decisive } \\
\text { factor }\end{array}$} & $\begin{array}{l}\text { Financial } \\
\text { reasons }\end{array}$ & 25.0 & 23.1 & 33.2 & 53.0 \\
\hline & Delays & 15.9 & 15.7 & 19.2 & 16.5 \\
\hline & Distance & 2.9 & 2.6 & 7.1 & 3.6 \\
\hline
\end{tabular}

Source: by the author from data of the 2014 EHIS-ESPS survey (Célant et al. 2017, pp. 132-145)

Note: the data concerning refusals for financial reasons are reconstructed data.

\section{Graph 1 -Changes in distribution by level of cover of beneficiaries between 2006 and 2013}



Source: DREES (2016, p. 45), from data on the most popular policies, 2006 and 2013 editions

Note: The policies are rated from the best cover (A) to the worst (E). For the methodology, see Garnero and Le Palud (2014).

The inequality in the issue of the financial accessibility of care resulting from the existence of the dependence of French households on complementary cover is coupled with the quality of the reimbursements offered by this cover. It stems from the segmentation created by the coexistence of individual and group cover. The group cover offered by the companies or branches is of systematically better quality than that available in the individual segment (Graph 1). Where 30 to $40 \%$ of beneficiaries only of group policies after 2010 receive bad or average cover (classes $\mathrm{C}$ to $\mathrm{E}$ ), this rises to $90 \%$ in the individual segment. This initially stems from the favourable position group requests have over suppliers, even if they are only very basically organised when compared to individual requests. This can also be seen in the distribution of policy expenses: in 2017, while policies had an average return on contributions in the form of 
benefits of around $79 \%$, this hides the fact that this ratio rises to $85 \%$ for group policies and falls to $73 \%$ for individual policies (Adjerad 2019, p. 3). From the perspective of inequalities between socio-economic groups, this disparity in reimbursements favours the most advantaged income groups (Graph 2); thus, only $8.4 \%$ of households with an income below $€ 650$ have group cover and this share increases in line with income to reach $51 \%$ for households with an income over $€ 3,000$. Thus, the segmentation of the complementary market between group and individual policies according to differences in the quality of reimbursements and access by the private salaried employee is broadly favourable to the wealthiest, especially managers. The withdrawal of part of the individual segment reduces the mutualisation margins for those people accessing it, which penalises salaried public employees ( $83 \%$ of individual cover), the selfemployed (78\%) and, in particular, retirees (94\%).

To a large extent, the social division in access to healthcare stems from a private health insurance market that replicates the inequalities of the labour market. This can also be seen in private sector employment: in 2009, $66.3 \%$ of salaried employees with permanent contracts accessed complementary cover through their company, as against $24.8 \%$ for those on fixedterm contracts (Perronnin et al. 2012, pp. 74-75). Finally, to the de facto subsidising by the employer's co-payment must be added the externalisation of the cost of the cover provided by the preferential tax/social security system. Thus, at the macroeconomic level based on values for 2014, the Inspectorate General of Social Affairs (IGAS) has estimated that the public authorities spent, via aid and reduced income, 6.4 to 8.3 billion euros on purchasing private health insurance (Bruant-Bisson and Daude 2016, p. 81). In this respect, aid for group policies for companies represents 3.5 and 5.4 billion euros, just over half the total amount. At the microeconomic level, simulations make it possible to estimate that this tax/social security system could represent subsidisation of up to $25 \%$ of the total amount, unevenly split between the employer and the employee. While this ultimately represents reduced spending on salaries for the employer, the employee benefits from it at the cost of a lesser entitlement to national social welfare schemes owing to a reduction in the basis for calculating contributions, caused by substituting salary with a contribution to complementary insurance (Zemmour 2015).

\section{Graph 2 - Rate of cover by complementary health insurance, based on income per consumption unit and the type of cover in $\mathbf{2 0 1 2}$}

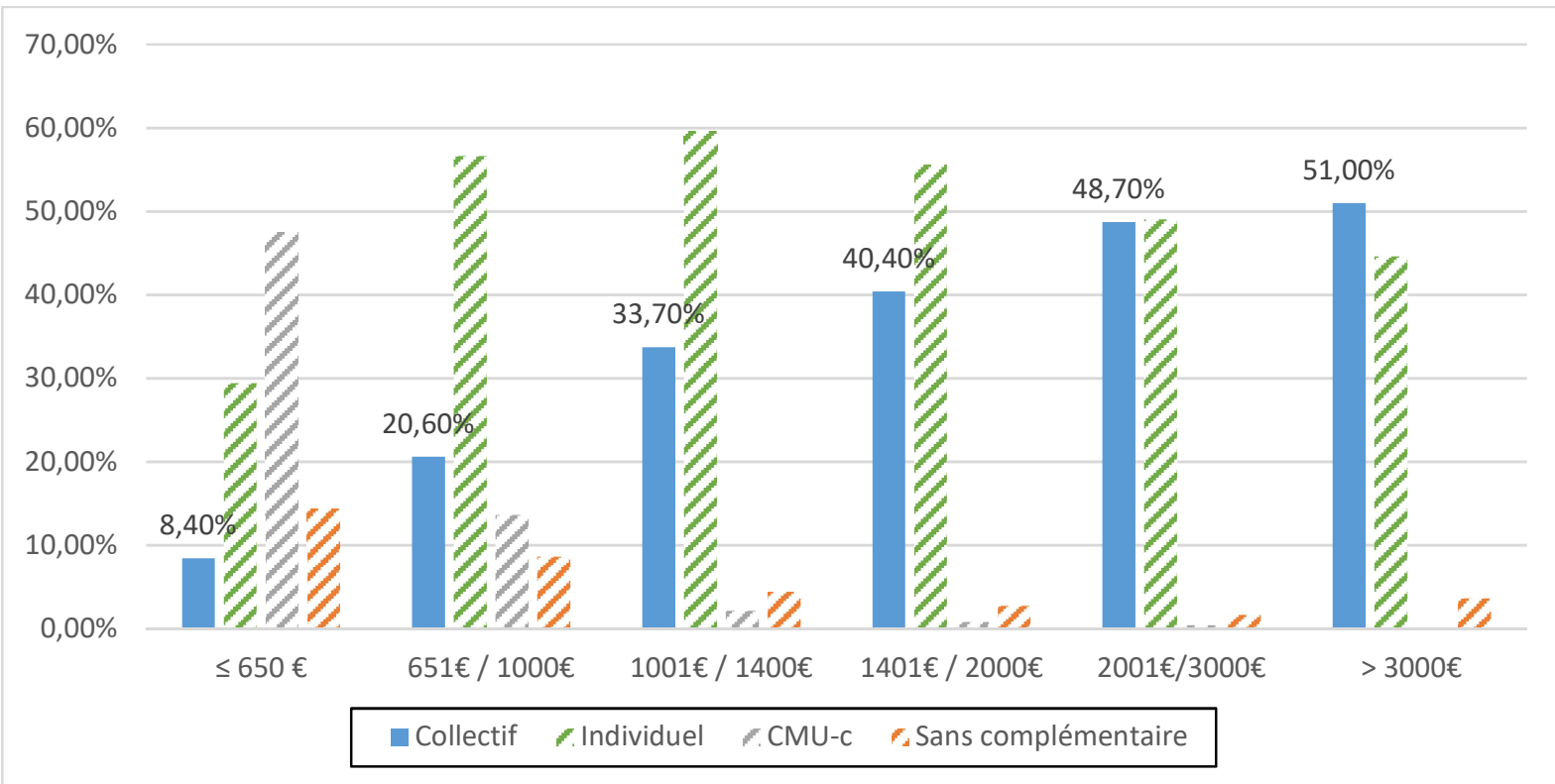

Source: DREES (2016, p. 53), from the 2012 ESPS survey, IRDES 


\section{The implications of the development of occupational health insurance for regulation by collective agreements: reflections on the French case}

The French Act of June 14, 2013 makes it mandatory for companies to provide complementary health insurance, thus institutionalising the status and role of collective insurance cover. The fact that the law makes this mandatory makes the French situation unprecedented, to say the least. Furthermore, over and above its particularities, analysing the French case through the lens of occupational welfare is a way of examining the role of collective bargaining in the design of occupational insurance. Doing so also offers insights into how occupational welfare is deployed in the EU legal environment which, by various regulatory means, enshrines the right to collective bargaining. The fact that, in France, occupational welfare entails employers taking out an insurance policy also raises the question as to whether social partners are capable of having an impact in the health insurance market and regulating it (4.1.). ${ }^{32}$ Ultimately, the core question under discussion here is the collective, solidarity-based dimension of occupational insurance (4.2.).

\subsection{Collective demand for insurance: how much room is there for collective bargaining?}

Positive EU law leaves plenty of room for collective bargaining in the realm of social protection (4.1.1.). However, the fact that collective bargaining is acknowledged as being able to play a role in this field at EU level does not compel Member States to grant any particular amount of room for collective demand for insurance. The French case offers interesting evidence in this respect (4.1.2.).

\subsubsection{Collective bargaining in social protection: the view from the top}

In the well-known Dutch case of Albany (the setting up of sector-based pension funds via a collective agreement) ${ }^{33}$, the ECJ took the view that the collective agreement setting up a complementary pension scheme addressed a social policy goal, since it was designed to ensure a set level of pensions for all workers within the occupational sector under consideration, thus directly contributing to the improvement of one of employees' working conditions, i.e. their compensation (albeit deferred compensation). In a subsequent ruling, a health care insurance scheme was analysed as contributing to the improvement of working conditions, by guaranteeing that workers had "the necessary means to meet medical expenses but also by reducing the costs which, in the absence of a collective agreement, would have to be borne by the employees" "34. More recently, the same reasoning was applied in the case of a collective agreement concluded in France in the artisanal bakery sector setting up complementary health insurance, with the reimbursement of healthcare costs "contributing to improved working conditions, 35 .

From this it follows that just like public authorities, social partners can achieve a degree of regulation in the field of social protection by negotiating collective agreements (Del Sol 2015). To do so, they have full autonomy to conclude an agreement and determine contents, since nothing in EU economic law requires them to adopt a particular definition of welfare benefits or determine the characteristics of the social protection scheme they intend to set up in any

\footnotetext{
${ }^{32}$ The issues are not the same when there is no requirement for insurance intermediation.

${ }^{33}$ ECJ case C-67/96, Albany, 21 September 1999 (point 59), ECR 1999, p. I-5751

${ }^{34}$ ECJ case C-222/98, Van der Woude, 21 September 2000 (point 25), ECR 2000, p. I-7111

${ }^{35}$ ECJ case C-437/09, AG2R, 3 March 2011, ECR 2011, p. I-973
} 
particular way. ${ }^{36}$ They may undertake minimal bargaining, or be more ambitious as to the type of benefits, the terms on which they are allocated, how much is allocated, and how they are funded.

This jurisprudence is all the more applicable in that article 28 of the Charter of Fundamental Rights, adopted in 2000, states that "Workers and employers... have... the right to negotiate and conclude collective agreements at the appropriate levels...". This relevance has been significantly heightened since the right to collective bargaining achieved the status of fundamental freedom in EU law. Indeed, when the Treaty of Lisbon was signed in 2009, the Charter of Fundamental Rights was granted the same legal value as the treaties themselves (art. 6§1 TFEU).

\subsubsection{Collective bargaining in social protection: the view from the bottom}

Despite a favourable EU legal environment, it cannot be asserted that collective bargaining is a "natural" vector for setting up social protection schemes in the occupational sphere, for instance to express a collective demand for health insurance. In reality, the role of collective bargaining in the field of social protection depends on parameters that are defined at the national level.

The French case constitutes a topical example of this issue. In 2013, a law was passed that enshrined the right to occupation-based complementary health insurance. It thus made this right dependent on a particular employment status and relationship, i.e. being an employee of a private-sector company. However, the occupational origins of this right do not automatically entail the cover being collective in nature. French regulations are ambiguous in this respect. Some aspects of the applicable legal framework could be understood as minimising the collective aspect, or the significance thereof. The following analysis is focused on the situation in France; nevertheless, it also raises broader issues whose implications could also emerge in other countries: firstly, the issue of potential competition between the legal vectors used to deploy occupational insurance; and secondly, the key issue of the degree to which regulation via collective bargaining can or may intervene.

Collective agreements as a vector of occupational social protection - exclusively, or in competition? For the purposes of deploying mandatory complementary health insurance, French law has prioritised implementation by means of collective bargaining. As a result, social partners in the relevant branch (sector of business) are the first to be required to deal with this new item in bargaining; if no agreement is reached at branch level, the law invokes the setting up of complementary health insurance by means of bargaining at company level.

However, branch or in-company negotiators are not bound by any obligation of results (i.e. concluding an agreement); they are bound only to a best effort undertaking. If no agreement is reached, the obligation to have insurance will be met by means of a unilateral decision on the part of the employer. Of course, any such decision does not rule out there having been prior consultation with employee representatives, but there is no legal requirement for any such consultation; neither is it consubstantial with this form of commitment. Determining the contents of health insurance is not put up for discussion with employee representatives, let alone the issue of having any solidarity parameters. In this case, the collective dimension is quantitative (the number of people insured), and not qualitative.

\footnotetext{
${ }^{36}$ However, the principles of non-discrimination and equality of treatment are also binding on social partners, as well as on the authorities.
} 
Moreover, this legal procedure is not agnostic in terms of who is actually covered. It must be combined with older legislation: France's Evin Law of December 31, 1989. Article 11 of this Law specifies that no employee present in the company at the time when an employer takes a unilateral decision to implement collective cover "may be compelled against their will to pay the relevant contributions...". All such employees are thus granted the right to refuse insurance if they are charged for part of its funding. A survey conducted to evaluate the effects of the 2013 Act for the first time highlights the finding that in fact, almost half of all newly-insured companies resorted to a unilateral decision by the employer (DRESS 2019). In these firms, the insured group may shrink due to a number of employees having opted not to sign up for the occupational insurance cover.

Contractual regulation - by sector or by company? In terms of social protection, it could be thought that negotiating a collective agreement is, other things being equal, the best way to bring the qualitative parameters of cover into the equation. However, resorting (whether exclusively or otherwise) to collective bargaining is not sufficient to take the collective dimension into account. Indeed, it must be emphasised that the level at which the agreement is concluded and its scope (sector of business or firm) may have an impact.

Historically, in France, the law has entrusted occupational branches (or sectors of business) with a key role in regulating complementary social protection, and in framing the standards that emerge at company level. While companies were left room to implement some degree of regulation, in most cases, this regulation has been secondary to that of the branch, or dependent on how the branch was regulated. More recent legislation (including an order dated September 22, 2017) has however led to this state of affairs being partially called into question, with regulation negotiated at company level becoming more autonomous in legal terms, including in the realm of top-up social protection (Vincent 2019; Rehfeldt and Vincent 2018). Moreover, it should be noted that this phenomenon of decentralisation of collective bargaining is a trend that may be observed in many EU countries, all the more so since the 2000s (European Commission 2012; Koukiadadi 2016; Müller 2019). The resulting retreat of sector-based regulation is not without its effects, irrespective of the subject under negotiation; indeed, it leads to a form of de-collectivisation (Laulom 2018). This effect is all the more acute when it comes to social protection, since decentralisation carries with it the seeds of a threat to both the scope and the degree of solidarity (see below) - and these are consubstantial components in any social protection scheme.

Some closing thoughts. At the time of the 2013 reform, France did not equip itself with any means to "counter" insurance market forces by giving any real preference to the demand for insurance from broad groups. This may come as a surprise inasmuch as the authorities have historically offered significant incentives to encourage the development of complementary social protection in the occupational sphere (see above). For instance, in 2003, the law opted to reserve such incentives for mandatory affiliation schemes for employees that were collective, i.e. benefiting all employees, or objectively determined categories of employee.

Indeed, mandatory collective insurance cannot be an emanation of insurance operators left to themselves. It can only be an emanation of the State ${ }^{37}$ or social partners, via collective bargaining. It may therefore appear paradoxical that French law has not granted exclusive accreditation to social partners to deploy mandatory complementary health cover benefiting employees. Indeed, this type of accreditation would be the only legal avenue via which a

\footnotetext{
${ }^{37}$ For instance, when they entrust a Social Security scheme to private-law bodies.
} 
collective demand for insurance could be established. However, in application of the 2013 Act, in the absence of any collective branch or company agreement, implementation is by means of a unilateral decision by the employer ${ }^{38}$; this does not express any collective demand. In other words, occupational health insurance cover is not necessarily cover that has been established collectively. The unilateral decision means that any policy taken out will cover only a specific set of employees. In one sense, this echoes the definition of "group insurance policy" given by the French Insurance Code (Code des assurances): a policy taken out by a legal person or head of establishment for the purposes of affiliating a number of individuals (subscribers) that must have a link of the same nature with the policyholder. The confines of the group are defined by the identity of the link with the policyholder, and not the links and/or interests that may unite the members of the group in question. By contrast, the vocation of a collective agreement is to cover a group of employees whose interests are taken into account by the employee negotiators with a view, in principle, to seeing the general interest of the group emerge in the negotiating process. $^{39}$

\subsection{Solidarity-based demand for insurance: how much autonomy do collective agreements provide?}

Since the Act of June 14, 2013, the role of collective occupational insurance in France has become institutionalised (see above). However, it should be borne in mind that occupationbased health insurance has long formed part of the market, more specifically the health insurance market. This raises the question of the extent to which collective agreements can affect competition between insurance companies on grounds of solidarity.

The issues. In a competitive system, demand (in theory) seeks to benefit from there being more than one supplier to obtain the best price (the concept of economic efficiency). Solidarity-based goals are therefore not defining features of this system; however, the latter does not necessarily ignore them altogether, either. The same therefore applies to EU competition law, which allows for adjustments of free competition in the presence of services of general economic interest (hereafter, SGEIs), for instance in the form of selective benefits or exclusive rights for certain suppliers. Thus, for example, in the field of social protection, the ECJ acknowledges the existence of SGEIs, in particular if solidarity-based elements are imposed on the managing operators of the schemes in place (see chapter 5). Indeed, it is generally argued that if the scheme is characterised by a degree of solidarity that imposes significant obligations on the managing insurer, the service the latter provides cannot be made available at the same price as that of other operators that are not subject to the same constraints. In other words, this insurer is less competitive on the insurance market because solidarity has a cost. ${ }^{40}$

This raises the issue of exclusive management rights being granted to a given insurance company. Indeed, these rights are the main legal vehicle by means of which solidarity can be

\footnotetext{
${ }^{38}$ The first data from after the 2013 Act emphasises the fact that the establishment of top-up health cover is not negotiated as a priority. It is frequently implemented by a decision on the part of the employer, in particular in very small establishments. See DREES 2019.

${ }^{39}$ On the difficulty of representing interests that can be divergent on a larger scale than that of the company or branch, see Ebbinghaus 2006.

${ }^{40}$ In the Albany case (previous ruling), the sector-based complementary pension scheme managed exclusively by a pension fund was characterised, in the Court's own words, by a high degree of solidarity. This was due, in particular, to the independence of contributions from the risk, the obligation to accept all workers without any prior medical examination, pensions continuing to be built up even without further contributions being paid in the event of incapacity for work, and the fund taking into account outstanding contribution payments due from the employer in the event of the latter's bankruptcy.
} 
introduced in the field of insurance. This is permitted by positive EU law. The latter allows for priority to be granted to a form of social protection that is partly protected from market forces (Laigre 1996; Driguez 2006; Del Sol 2016). When this paradigm shift occurred in 2013, France seems to have missed an opportunity to establish private collective insurance incorporating a high degree of solidarity. The main reason for this is to do with the way the right to collective bargaining has been made somewhat secondary, since collective agreements can no longer assign a management monopoly to an insurer.

How collective bargaining rights have become secondary in the French reform. Collective agreements give social partners the ability to establish a health insurance regime that is structurally solidarity-based and fulfils the criteria to qualify as an SGEI. The degree of differentiation from the operation of "traditional" private insurance present on the market is what makes it possible to assess the implementation of the solidarity principle and thus provide justification for adjusting these rules of competition. The collective agreement should therefore not simply consist of a set of guarantees, but rather establish a fully-fledged scheme. The rules configuring the degree of proportionality that is normally established in insurance between contributions and risks, as well as between contributions and benefits, therefore become crucial; everything thus depends on the degree to which this configuration alters the traditional workings of risk-based insurance. This is, in substance, what emerges from the $A G 2 R$ ruling (op. cit.) in which the ECJ refers to a number of factors: funding by means of fixed-rate contributions, such that the rate is not proportional to the insured risk, with the result that age, state of health, and particular risks inherent in the position occupied are not taken into consideration $^{41}$; the type of benefits and extent of cover not being proportional to the amount of contributions paid; the existence of "free" entitlements not directly related to a contribution (e.g. the temporary maintenance of cover for heirs in the event of the death of the employee).

If the collective agreement is concluded at the level of a branch and management of the social protection scheme has been outsourced to an insurance body, the general-interest missions are usually accomplished by granting exclusive management rights to the insurer, failing which the economic conditions would not be acceptable for it and in some cases could threaten its financial equilibrium. To facilitate this, positive EU law allows for the collective agreement itself to grant a management monopoly to an insurance company. This monopoly may thus arise from the inclusion in the collective agreement of a clause designating the insurance company that will manage the negotiated scheme; this clause then requires companies in the branch to take out a collective insurance policy with the designated insurer.

However, in 2013, the French Constitutional Council ruled the contractual clauses on designation invalid. In doing so, it closed the door to the establishment of collective insurance that was solidarity-based in structural terms, on the grounds of the freedom of contract for employers, as well as the freedom of enterprise (Kessler 2015). Indeed, henceforth, social partners in a branch can no longer impose the insurance body on companies in the sector of business in question. At best, the collective agreement may include a recommendation clause, but this nevertheless allows firms full freedom to choose the insurance company - the one recommended by the branch, or another insurer. As a result, it is no longer possible to create genuine occupational social protection schemes, since no insurance company would agree to ensure a strongly solidarity-based scheme without being able to count on every firm within the branch. The right to collective bargaining is therefore limited, and in a certain sense relegated, with the employer's freedom of contract being granted superior status. This leads to a

\footnotetext{
${ }^{41}$ In other words, pricing was not determined on the basis of each employee's loss experience.
} 
paradoxical state of affairs: while the specifically social function of the designation clauses makes them fully compliant with EU competition law, they have disappeared from French law because they run counter to the French constitutional principle of freedom of contract.

Moreover, if there is no branch agreement, or the agreement does not have a recommendation clause, the concept of pooling between firms within the occupational sector in question also runs into difficulties. Firms are thus subject to the law of the market and nothing else, and have to take out a policy directly from an insurance company. Given this state of affairs, when establishing pricing for the policy, the insurance company will perform an actuarial analysis of the risks, taking into account factors such as the size of the company, its loss experience (e.g. the rate of occupational accidents and diseases), absenteeism, and certain demographic factors (such as sex, age, and state of health). Firms may be faced with a range of rates for equivalent levels of cover. As a result, firms with low bargaining power (often the case for smaller companies) are penalised, since no pooling with larger firms at branch level is organised. Ultimately, this penalisation may impact employees, since their share of the funding may be higher, or the levels of cover lower, in order for the cost to be affordable.

As C. Vincent has quite rightly pointed out, "the practical conditions in which complementary health insurance has been implemented have opened up the way for the health risk market to be reconfigured. Local, autonomous regulation is taking the place of historic national governance" (Vincent 2019).

A potential challenge to the relegation of collective bargaining rights? In the realm of topup health insurance, the disappearance of designation clauses would appear to sound the death knell of the idea of an entire occupational branch approaching private social insurance companies. The ruling by the French Constitutional Council also "mistreats" the right to collective bargaining by restricting the freedoms of social partners. However, the European legal environment has enshrined the right to collective bargaining via a variety of legal vectors. Firstly, article 28 of the Charter of Fundamental Rights of the EU recognises the right of collective bargaining and action (Dorssemont and Rocca 2019); secondly, article 6 of the European Social Charter asserts "the right of workers and employers to collective action in cases of conflicts of interest" 42 ; in principle, this compels the large number of Member States who have signed or ratified the Charter to adopt the necessary measures to ensure that this right can actually be exercised. ${ }^{43}$ Indeed, it is on the grounds of a breach of this article 6 that a French trade union federation, Force Ouvrière, decided to bring a case before the European Committee of Social Rights (hereafter, ECSR) as part of a collective complaint.

The trade union argued that the fact that social partners cannot make use of designation clauses of which the purpose is to pool risks at branch level constitutes unjustified interference in the right to collective bargaining and is detrimental to the right of social partners to negotiate freely. The ECSR upheld the trade union's argument, taking the view that the prohibition of designation clauses was in breach of article $6 \$ 2$ of the Charter. ${ }^{44}$ In particular, it specified that there was "no fundamental reason to uphold freedom of contract on the right to collective bargaining” (\$68). As one author put it, "the ECSR ruling establishes equivalency between

\footnotetext{
${ }^{42}$ It is worth noting that article 6 is in the part of the Charter entitled "Solidarity".

${ }^{43}$ This Charter has been adopted, not by the European Union, but by the Council of Europe. It is controlled by the European Committee of Social Rights by means of two mechanisms (national reports and collective complaints). However, the rulings handed down by the Committee are not enforceable in domestic legal orders.

${ }^{44}$ ECSR, 3 July 2018, Confédération Générale du Travail Force Ouvrière (FO) vs. France, complaint no. 118/2015
} 
economic freedoms and the right to collective bargaining"; "by positioning itself in such a way as to focus on an assessment of the seriousness of the legislative measure in terms of its impact on the right to collective bargaining, the ECSR has not addressed the question in mere technical terms, but rather in terms of values" (Ginon 2019). This does not grant social partners carte blanche though, because it does not establish any precedence of the right to collective bargaining over economic freedoms either. Everything is a matter of proportionality. The ECSR's assessment of proportionality has led to it emphasising that "the designation of an insurer by the social partners was a mechanism based on the principle of solidarity" (\$72), contrary to the mechanism of the recommendation, which "leads to a complementary "twotrack' social protection scheme" $(\$ 73)^{45}$.

Similarly, to the ECJ jurisprudence on SGEIs in terms of competition law, the ECSR has staked out a possible route towards balancing market principles and social interests. The issue here is to avoid a form of Balkanisation of occupational complementary social protection schemes ${ }^{46}$ liable to penalise the most vulnerable employees and the smallest firms. In France, it is now up to the authorities to alter the trajectory set by the Constitutional Council's ruling. It would appear that an alternative path can be traced. However, this would entail taking the ECSR's ruling, which is not binding, into account, and in doing so, adding grist to the social partners' mill. Such an outcome appears unlikely. Indeed, the 2013 Act has in fact established a right to complementary health insurance for employees in the private sector. This right is a means of redistributing the public and private-sector funding of health insurance for a large part of the population. Seen thus, the ambiguous role assigned to collective bargaining is doubtless not as paradoxical as it might appear at first sight; promoting an aspect of collective bargaining was not in fact its intended aim.

\section{Conclusion}

Despite the fact that the vast majority of individuals (more than 95\%) have complementary health cover in France, the government has made complementary insurance compulsory for a section of the population (salaried employees in the private sector), although it has traditionally been voluntary. This development reveals the heights reached by the marketisation of health insurance, as the requirement to take out private health cover is now institutionalised. As a result, this extension of complementary cover could be seen as contributing to the privatisation or commodification process of health insurance. This type of analysis, commonly used, takes the public-private mix as its point of reference and provides information on the role of the State, the existence of non-State players (such as firms, social partners, insurers) and the place of the market. Such a point of reference could be used for all social risks. It also facilitates a comparative approach between national systems, as it ultimately enables a sort of architectural modelling of the systems.

In view of the very high level of complementary cover that existed prior to the 2013 law, however, this marketing does not significantly alter the balance between public and private insurance. On the other hand, by choosing to favour group insurance and requiring employers to provide at least half of the funding for the health cover of their staff, one enters the domain of occupational welfare, which is consequently positioned on the market. This marketing dimension created by the 2013 law has a certain uniqueness. The chapter therefore took the

\footnotetext{
${ }^{45}$ The Committee criticised the very broad nature of the prohibition against designation clauses. It took the view that doing so failed to take into account 'certain branches with specific needs, presenting 'bad risks' or activities where employees frequently change employers” (\$74).

${ }^{46}$ One author talks in terms of “a myriad of independent micro-perimeters" (Petit 2019).
} 
option of employing those works dedicated to occupational welfare. The aim was to have an analytical framework that makes it possible to grasp the complexity and the institutional complementarities between the different components of a system. It was a matter of using a framework seen as more "receptive" to complex and original institutional configurations. By placing occupational welfare schemes at the centre of the analytical framework (here, in the area of health cover), it is possible to examine several aspects of the system: the role of the State (if necessary via tax incentive policies promoting occupational insurance cover) and of the market; the distribution of roles in meeting the social requirement to pay for health care; the systemic effects of institutional arrangements in terms of solidarity. In our view, this justifies the preference for the expression "welfare mix" rather than "public-private mix". Thus, while the existence of non-State players can be an indicator, or even a criterion, of the privatisation of financing, it can also reveal a lot more about the system when it is combined with other aspects; for example, some non-State players can, through their involvement or by "allocation", represent alternatives between the State and the market.

However, this analytical framework is not well suited to the modelling of national systems. On the other hand, with its multi-dimensional interpretation of a system, it can make its realities more intelligible and consequently provide general keys to the understanding of a particular case. Thus, the evolution of the French case cannot be reduced to new balances within the health insurance market between individual and group insurance. On the contrary, the analysis performed makes it possible to grasp the issues and systemic effects of the reconfiguration that has taken place. It underlines the way in which it affects the welfare mix and its capacity to satisfy the need for the provision of care. The occupational welfare prism is of relative interest in understanding the financing privatisation process. It is, however, particularly relevant when it comes down to analysing the very substance of a social protection system, especially in relation to health cover. What is true for the analysis of the French case is also true for other national systems, despite the notable differences between them. Indeed, the health problem is universal and can be viewed independently of the employment status. It is connected to public health issues, to the interactions with healthcare service providers and to questions of both horizontal (between the healthy and the sick) and vertical (between income groups) redistribution. The mobilisation, or even instrumentalisation, of professional (and therefore category-based) insurance cover is therefore not a neutral policy choice, regardless of whether the choice is strategic or more accidental.

If we look beyond the analytical aspect alone, the French case is a strong indicator of the solidarity issues that can be highlighted by the occupational welfare systems. They force us to (re-)consider the question of solidarities, which is important, or even central, when protection against health risks is at stake. We must first take a look at occupational welfare, as a component of the system; a look that will in a way be introspective. Unlike public social security schemes, the occupational welfare systems are not, by definition, structured by a principle of solidarity. On the other hand, by construction, they can be infused with a solidarity whose form, extent and degree are all variables.

However, the question of solidarity does not stop at the borders of the professional "pillar". In the field of health cover, the occupational welfare systems certainly have the potential to be established between the State and the market, and even to be an alternative to the market: they can instil solidarity, unlike individual private health insurance, which would not be regulated, without, however, being able to be as ambitious as a compulsory legal social security scheme based on a principle of national solidarity. As a result, it is the solidarity of the system as a whole that is impacted by the occupational welfare systems. The view taken must 
be quite panoramic in order to appreciate the links between the various components of the system and the distribution of solidarity produced by the institutional arrangements. And yet, in terms of solidarity, these arrangements will produce effects that are necessarily dependant on choices related to occupational welfare. This could result in welfare mix configurations that are extremely variable from one system to the next, with the (apparent) paradox that a high level of solidarity within the occupational "pillar" could destabilise the systemic solidarity. 


\section{$\underline{\text { References }}$}

Adjerad, R. (2019). Complémentaire santé : la hausse modérée de la part des contrats collectifs se poursuit en 2017. Études \& Résultats, 1112. Paris, Direction de la Recherche, des Études, de l'Évaluation et des Statistiques (DREES).

Amable, B. (2004). The Diversity of Modern Capitalism. Oxford: Oxford University Press, 326 p.

Amable, B., \& Palombarini, S. (2009), A neorealist approach to institutional change and the diversity of capitalism. Socio-Economic Review, 7(1), 123-143.

André, C., Batifoulier, P., \& Jansen-Ferreira, M. (2016). Health care privatization processes in Europe: Theoretical justifications and empirical classification. International Social Security Review, 69(1), 3-23.

Aoki, M. (2001). Toward a Comparative Institutional Analysis. Cambridge (MASS.): MIT Press, $480 \mathrm{p}$.

ApRoberts, L. (1996). Les acteurs sociaux selon la doctrine de la Banque Mondiale. La Lettre de l'Observatoire des Retraites, 8(9).

Banque Mondiale (1994). Averting the Old Age Crisis: Policies to Protect the Old and Promote Growth. Policy Research Report. Oxford: Oxford University Press \& World Bank.

Barbier, J.-C., \& Théret, B. (2009). Le système français de protection sociale. Paris : La Découverte (Repères), $128 \mathrm{p}$.

Batifoulier, P. (2012). De la responsabilité individuelle aux priorités collectives. Une analyse institutionnaliste des politiques de la demande de santé. Éthique et économique/Ethics and Economics, 9(2), 25-44.

Batifoulier, P., Domin, J.-P., Gadreau, M. (2007). La gouvernance de l'assurance maladie au risque d'un État social marchand. Économie Appliquée, 60(1), 101-126.

Batifoulier, P., Domin, J.-P., Gadreau, M. (2008). Mutation du patient et construction d'un marché de la santé. L'expérience française. Revue Française de Socio-Économie, 1, 27-46.

Bönker, F. (2005). Changing Ideas on Pensions: Accountig for Differences in the Spread of the Multipillar Paradigm in Five EU Social Insurance Countries. In P. Taylor-Gooby (Ed.), Ideas and Welfare State Reform in Western Europe. Hampshire: Palgrave Macmillan.

Bruant-Bisson, A., \& Daude, M. (2016). Contribution au rapport au Parlement sur les aides fiscales et sociales à l'acquisition d'une complémentaire santé, 2015-143R. Paris : Inspection Générale des Affaires Sociale (IGAS).

Bruun, N., Lörcher, K., Schömann, I. \& Clauwaert, S. (Eds.) (2016). The European Social Charter and the Employment Relation. Oxford: Hart Publishing, 536 p. 
Castel, R. (1999). Les métamorphoses de la question sociale. Une chronique du salariat. Paris : Folio (Folio Essais), 813 p.

Castel, R. (2002). From Manual Workers to Wage Laborers: Transformation of the Social Question. Piscataway: Transaction Publishers, 496 p.

Célant, N., Guillaume, S., \& Rochereau, T. (2017). Enquête Santé Européenne - Enquête Santé et Protection Sociale 2014 (EHIS-ESPS), 566. Paris: Institut de Recherche et de Documentation en Économie de la Santé (IRDES).

Cutler, T., \& Waine, B. (2001). Social Insecurity and the Retreat from Social Democracy: Occupational Welfare in the long boom and financialization. Review of International Political Economy, 8(1), 96-118.

De Deken, J. (2018). The corrosion of occupational pensions solidarity in the Netherlands. Transfer: European Review of Labour and Research, 24(1), 43-56. https://doi.org/10.1177/1024258917748274

Deeg, R. (2007). Complementarity and institutional change in capitalist systems. Journal of European Public Policy, 14(4), 611-630.

Del Sol, M. (2014). Généralisation de la couverture complémentaire santé des salariés: éléments de controverse. Droit social, 165-173.

Del Sol, M. (2015), Droit européen et protection sociale négociée : mesure de l'autonomie des partenaires sociaux. In P. Turquet (Ed.), La crise de la protection sociale en Europe. Adaptation ou refondation (pp. 95-105). Rennes : Presses Universitaires de Rennes.

Del Sol, M. (2016). Protection sociale : le droit de l'Union européenne entre monopole et concurrence. In M. Borgetto, A.-S. Ginon \& F. Guiomard (Eds.), Quelles(s) protection(s) sociale(s) demain? (pp. 107-125). Paris : Dalloz (Thèmes et commentaires).

D.G. Trésor (2015). Quel avenir pour le dispositif de prise en charge des affections de longue durée (ALD) ?. Lettre Trésor-Eco, 145. Paris : Ministère de l'Economie et des Finances.

Dormont, B., Geoffard, P.-Y., \&Tirole, J. (2014). Rebuilding the Health Insurance System. Publication web sérielle, Notes $d u$ CAE, 42. Paris : Conseil d'Analyse Economique (CAE).

Dorssemont, F., Lörcher, K., Clauwaert, S. \& Schmitt, M. (Eds.) (2019). The Charter of Fundamental Rights of the European Union and the Employment Relation. Oxford: Hart Publishing, $712 \mathrm{p}$.

Dorssemont, F. \& Rocca M. (2019). Article 28 - Right of Collective Bargaining and Action. In F. Dorssemont, K. Lörcher, S. Clauwaert \& M. Schmitt (Eds.), The Charter of Fundamental Rights of the European Union and the Employment Relation. Oxford: Hart Publishing.

Dorssemont, F. (2016). The Right to Bargain Collectively: A Matrix for Industrial Relations. In N. Bruun, K. Lörcher, I. Schömann \& S. Clauwaert (Eds.), The European Social Charter and the Employment Relation. Oxford: Hart Publishing. 
Dourgnon, P., Jusot, F., \& Fantin, R. (2012). Payer nuit gravement à la santé : une étude de l'impact du renoncement financier aux soins sur l'état de santé. Économie publique/Public economics, 28-29, 123-147.

Dourgnon, P., Or, Z., \& Sorasith, C. (2013). The Impact of the Long-term Illness Scheme (LTI) on Inequalities in the Utilisation of Ambulatory Care Between 1998 and 2008. Publication web sérielle, Question d'économie de la santé, 183. Paris: Institut de Recherche et de Documentation en Économie de la Santé (IRDES).

DREES (2016). Les complémentaires santé. Acteurs, bénéficiaires, garanties. Édition 2016, Panoramas de la DREES, S 16-070. Paris: Direction de la Recherche, des Études, de l'Évaluation et des Statistiques (DREES).

DREES-IRDES (2019). Enquête PSCE - Protection sociale complémentaire d'entreprise. Paris : Direction de la Recherche, des Études, de l'Évaluation et des Statistiques (DREES).

Driguez, L. (2006). Droit social et droit de la concurrence. Bruxelles : Bruylant.

Dreyfus, M. (2009). L'émergence tardive des assurances sociales en France. In M. Dreyfus (Ed.), Les assurances sociales en Europe (pp.79-129). Rennes : Presses Universitaires de Rennes (Pour une histoire du travail).

Ebbinghaus, B. (2006). Trade union movements in post-industrial welfare states: opening up to new social interests?. In K. Armingeon \& G. Bonoli (Eds.) The politics of post-industrial welfare states: adapting post-war social policies to new social risks (pp. 123-142). London: Routledge.

Ebbinghaus, B. (2011a). Introduction: Studying Pension Privatization in Europe. In B. Ebbinghaus (Ed.), The Varieties of Pension Governance: Pension Privatization in Europe (pp. 3-22). Oxford: Oxford University Press.

Ebbinghaus, B. (Ed.) (2011b). The Varieties of Pension Governance: Pension Privatization in Europe. Oxford: Oxford University Press, 440 p.

European Commission (2012). Labour Market Developments in Europe 2012. European Economy, 5. Brussels.

Evans, R.G. (1974). Supplier-Induced Demand: Some Empirical Evidence and Implications. In M. Perlman (Ed.), The Economics of Health and Medical Care: Proceedings of a Conference held by the International Economic Association at Tokyo (pp. 162-173). Londres: Palgrave Macmillan UK (International Economic Association Series).

Farnsworth, K. (2004). Welfare through Work: An Audit of Occupational Social Provision at the Turn of the New Century. Social Policy \& Administration, 38(5), 437-455.

Farnsworth, K. (2012). Occupational welfare. In B. Greve (Ed.), The Routledge Handbook of the Welfare State (pp. 30-39). Oxon: Routledge (Routledge Handbooks).

Franc, C. (2017). Le partage de la couverture maladie entre assurances obligatoire et complémentaires - Les défauts d'un système mixte. Médecine/Sciences, 33(12), 1097-1104. 
Friot, B. (2012). Puissances du salariat. Paris : La Dispute (Travail et salariat), 438 p.

Garnero, M., \& Le Palud, V. (2014). Les contrats les plus souscrits auprès des complémentaires santé en 2010. Document de travail, Série Statistiques, 191. Paris : Direction de la Recherche, des Études, de l'Évaluation et des Statistiques (DREES).

Ginon, A.-S. (2019). Réflexions sur les clauses de désignation : du Conseil constitutionnel au Comité européen des droits sociaux. Revue de droit sanitaire et social, 331-343

Goodin, R.E., \& Rein, M. (2001). Regimes on Pillars: Alternative Welfare State Logics and Dynamics. Public Administration, 79(4), 769-801.

Greve, B. (2007). Occupational welfare. Winners and Losers. Cheltenham: Edward Elgar Publishing, $208 \mathrm{p}$.

Greve, B. (2018). At the heart of the Nordic occupational welfare model: Occupational welfare trajectories in Sweden and Denmark. Social Policy \& Administration, 52(2), 508-518.

Hacker, J.S. (2002). The Divided Welfare State. The Battle over Public and Private Social Benefits in the United States. NewYork: Cambridge University Press, 466 p.

Hacker, J.S. (2004), Privatizing Risk without Privatizing the Welfare State: The Hidden Politics of Social Policy Retrenchment in the United States. The American Political Science Review, 98(2), 243-260.

Hall, P.A., \& Soskice D. (2001). Introduction. In P.A. Hall P.A. \& D. Soskice (Eds.), Varieties of Capitalism: The Institutional Foundations of Comparative Advantage (pp. 1-68). Oxford: Oxford University Press.

Hassenteufel, P., \& Palier, B. (2007). Towards Neo-Bismarckian Health Care States? Comparing Health Insurance Reforms in Bismarckian Welfare Systems. Social Policy \& Administration, 41(6), 574-596.

Hatzfeld, H. (1971). Du paupérisme à la Sécurité sociale, 1850-1940. Nancy: Presses Universitaires de Nancy.

Häusermann, S. (2010). The Politics of Welfare State Reform in Continental Europe. Modernization in Hard Times. Cambridge: Cambridge University Press (Cambridge Studies in Comparative Politics).

HCAAM (2011). L'assurance maladie face à la crise. Mieux évaluer la dépense publique d'assurance : l'ONDAM et la mesure de l'accessibilité financière des soins. In HCAAM, Rapport d'activité. Paris : Haut Conseil pour l'Avenir de l'Assurance Maladie (HCAAM).

HCAAM (2013). Rapport d'activité 2013. Paris : Haut Conseil pour l'Avenir de l'Assurance Maladie (HCAAM).

Howard, C. (1997). The Hidden Welfare State: Tax Expenditure and Social Policy in the United States. Princeton: Princeton University Press (Princeton Studies in American Politics: Historical, International, and Comparative Perspectives), 266 p. 
Immergut, E.M., Anderson, K.M., \& Schulze, I. (Eds.) (2006), The Handbook of Western European pension politics. Oxford: Oxford University Press, 965 p.

Jacobs, A. (2013). The Right to Bargain Collectively under Article 11 ECHR. In F. Dorssemont, K. Lörcher \& I. Schömann (Eds.), The European Convention on Human Rights and the Employment Relation. Oxford: Hart Publishing.

Järvi, L., \& Kuivalainen, S., (2013). Equally to All? The Significance of Collectively Negotiated Sickness Benefits in Cross-Nordic Social Policy Analysis. European Journal of Social Security, 15(4), 341-357.

Johnson, N. (1999). Mixed Economics of Welfare: A Comparative Perspective. London: Prentice Hall Europe, 309 p.

Johnston, A., Kornelakis, A., \& d'Acri, C.R. (2011). Social partners and the welfare state: Recalibration, privatization or collectivization of social risks?, European Journal of Industrial Relations, 17(4), 349-364.

Jusot, F. (2013). Les inégalités de recours aux soins : bilan et évolution. Revue d'Épidémiologie et de Santé Publique, 61, S163-S169.

Jusot, F., Legal, R., Louvel, A., Pollak, C., \& Shmueli, A. (2017). Public and Private Health Insurances: How do they Contribute to Social Solidarity. Publication web sérielle, Question d'économie de la santé, 225. Paris : Institut de Recherche et de Documentation en Économie de la Santé (IRDES).

Kerleau, M. (2009). Le nouveau cadre institutionnel de la protection sociale complémentaire d'entreprise: quels enjeux pour les mutuelles santé ?. Revue internationale de l'économie sociale (RECMA), 312, 15-34.

Kerleau, M. (2012). De la couverture maladie universelle aux politiques d'accès à l'assurancemaladie complémentaire : diversité des modèles et des protections. Revue Française de SocioÉconomie, 9, 171-189.

Kerleau, M., Durand, F., Fretel, A., Hirtzlin, I. (2008). Pratiques et enjeux autour de la protection sociale complémentaire d'entreprise. Tome 1, Rapport de recherche, Mire « Gouvernance de la protection sociale ». Paris : Centre d'Économie de la Sorbonne.

Kessler, F. (2015). L'émergence (trop tardive ?) de la notion de régime de protection sociale complémentaire. Revue de droit sanitaire et social, 352-363

Koukiadaki, A., Tavora, I., \& Martinez Lucio, M. (Eds.) (2016). Joint Regulation and Labour Market Policy in Europe During the Crisis. Brussels: European Trade Unions Institute (ETUI).

Laigre, P. (1996). L'intrusion du droit communautaire de la concurrence dans le champ de la protection sociale. Droit social, 82-90

Laulom, S. (2017). From decentralisation of collective bargaining to de-collectivisation of industrial relations systems?. In S. Laulom (Ed.), Collective bargaining developments in times of crisis (pp. 15-28). Kluwer Law International, Bulletin of Comparative Labour Relations. 
Laulom, S., (Ed.) (2017). Collective bargaining developments in times of crisis. Kluwer Law International, Bulletin of Comparative Labour Relations, 368 p.

Legal, R., Raynaud, D., \& Vidal, G. (2009). La prise en charge des dépenses maladie des assurés sociaux en fonction du risque constaté : quelle contribution de l'assurance maladie et des organismes complémentaires ?. In Comptes nationaux de la Santé 2009 (pp. 57-69). Paris : Direction de la Recherche, des Études, de l'Évaluation et des Statistiques (DREES).

Leimgruber, M. (2012). The historical roots of a diffusion process: The three-pillar doctrine and European pension debates (1972-1994). Global Social Policy, 12(1), 24-44.

Mares, I. (2003). The Politics of Social Risks. Business and Welfare State Development. Cambridge: Cambridge University Press, 344 p.

Mishra, R. (1990). The welfare state in capitalist society: Policies of retrenchment and maintenance in Europe, North America, and Australia. New York: Harvester Wheatsheaf, $152 \mathrm{p}$.

Montaut, A. (2018). Tarifs et prestations : que révèle le nom des organismes de complémentaire santé ?. Publication web sérielle, Études \& Résultats, 1047. Paris : Direction de la Recherche, des Études, de l'Évaluation et des Statistiques (DREES).

Müller, T., Vandaele, K., \& Waddington, J. (Eds) (2019). Collective bargaining in Europe: towards and endgame. Brussels: European Trade Unions Institute (ETUI), 238 p.

Naczyk, M. (2013). Agents of privatization? Business groups and the rise of pension funds in Continental Europe. Socio-Economic Review, 11(3), 441-469.

Naczyk, M., \& Seeleib-Kaiser, M. (2015). Solidarity against All Odds: Trade Unions and the Privatization of Pensions in the Age of Dualization. Politics \& Society, 43(3), 361-384.

Natali, D., Pavolini, E., \& Vanhercke, B. (Eds.) (2018). Occupational Welfare in Europe: Risks, opportunities and social partner involvement. Brussels: European Trade Unions Institute (ETUI) \& Observatoire Social Européen (OSE), 2018 p.

Nyman, J.A. (1999a). The value of health insurance: the access motive. Journal of Health Economics, 18(2), 141-152.

Nyman, J.A. (1999b). The economics of moral hazard revisited. Journal of Health Economics, $18(6), 811-824$

Palier, B. (2010). The Long Conservative Corporatist Road to Welfare Reforms. In B. Palier (Ed.), A Long Goodbye to Bismarck? The Politics of Welfare Reforms in Continental Europe (pp. 333-387). Amsterdam: Amsterdam University Press (Changing Welfare States).

Palier, B. (2017). La réforme des systèmes de santé. Paris : Presses Universitaires de France (PUF) (Que sais-je ?), 128 p.

Palier, B., \& Thelen, K. (2010). Institutionalizing Dualism: Complementarities and Change in France and Germany. Politics \& Society, 38(1), 119-148. 
Pauly, M.V. (1968). The Economics of Moral Hazard: Comment. The American Economic Review, 58(3), 531-537.

Perronnin, M., Pierre, A., \& Rochereau, T. (2012). Enquête sur la protection sociale complémentaire d'entreprise en France (PSCE 2009), 554. Paris : Institut de Recherche et de Documentation en Économie de la Santé (IRDES).

Petit, B. (2019). Clauses de désignation : le Conseil constitutionnel désavoué par le Comité européen des droits sociaux, Revue des droits et libertés fondamentaux, chron. $\mathrm{n}^{\circ} 05$. http://www.revuedlf.com/droit-social/clauses-de-designation-le-conseil-constitutionneldesavoue-par-le-comite-europeen-des-droits-sociaux-ceds-3-juillet-2018-cgt-fo-c-francen118-2015/

Powell, M. (Ed.) (2007a). Understanding the mixed economy of welfare. Basingstoke: Bristol University Press (Understanding Welfare: Social Issues, Policy and Practice), 272 p.

Powell, M. (2007b). The mixed economy of welfare and the social division of welfare. In M. Powell (Ed.), Understanding the mixed economy of welfare (pp. 1-21). Basingstoke: Bristol University Press (Understanding Welfare: Social Issues, Policy and Practice).

Ramaux, C. (2007). Quelle théorie pour l'État social? Apports et limites de la référence assurantielle. Revue française des affaires sociales, 1, 13-34.

Ramaux, C. (2012). L'État social. Pour sortir du chaos néolibéral. Paris : Mille et une nuits (Essai), $470 \mathrm{p}$.

Rehfeldt, U., \& Vincent, C. (2018). The decentralisation of collective bargaining in France: an escalating process. In S. Leonardi \& R. Pedersini (Eds.), Multi-employer bargaining under pressure: decentralisation trends in five European countries (pp. 151-184). Brussels: European Trade Unions Institute (ETUI).

Rein, M. (1982). The Social Policy of the Firm. Policy Sciences, 14(2), 117-135.

Rein, M. (1996). Is America Exceptional? The Role of Occupational Welfare in the United States and the European Community. In M. Shalev (Ed.), The Privatization of Social Policy? Occupational Welfare and the Welfare State in America, Scandinavia and Japan (pp. 27-43). Basingstoke: Palgrave Macmillan.

Rein, M., \& Wadensjö, E. (1998). Enterprise and the Welfare State. Cheltenham: Edward Elgar Publishing, $416 \mathrm{p}$.

Seeleib-Kaiser, M., \& Fleckenstein, T. (2009). The Political Economy of Occupational Family Policies: Comparing Workplaces in Britain and Germany. British Journal of Industrial Relations, 47(4), 741-764.

Shalev, M. (Ed.) (1996). The Privatization of Social Policy? Occupational Welfare and the Welfare State in America, Scandinavia and Japan. Basingstoke: Palgrave Macmillan, 383 p.

Sinfield, A. (1978). Analyses in the Social Division of Welfare. Journal of Social Policy, 7(2), 129-156. 
Spaeth, J.-M. (2008). Les syndicats et l'assurance maladie. Les Tribunes de la santé, 18, 29-37.

Streeck, W., \& Schmitter, P.C. (1985). Community, Market, State-and Associations? The Prospective Contribution of Interest Governance to Social Order. European Sociological Review, 1(2), 119-138.

Swenson, P. (1991). Bringing Capital Back in Social Democracy Reconsidered: Employer Power, Cross-Class Alliances, and Centralization of Industrial Relations in Denmark and Sweden. World Politics, 43(4), 513-544.

Tabuteau, D. (2010). La métamorphose silencieuse des assurances maladie. Droit social, 85-92.

Thelen, K. (1993). West European Labor in Transition: Sweden and Germany Compared. World Politics, 46(1), 23-49.

Titmuss, R.M. (1958). The Social Division of Welfare: Some Reflections on the Search for Equity. In R. M. Titmuss (Ed.), Essays on the «Welfare State (pp. 34-54). Londres: Allen \& Unwin.

Trampusch, C. (2007). Industrial Relations as a Source of Social Policy: A Typology of the Institutional Conditions for Industrial Agreements on Social Benefits. Social Policy \& Administration, 41(3), 251-270.

Trampusch, C. (2009). Collective agreements on pensions as a source of solidarity. Journal of Comparative Social Welfare, 25(2), 99-107.

Vincent, C. (2019). La reconfiguration du marché du risque santé par la négociation : de l'interprofessionnel à l'entreprise et du contrat individuel au collectif. Revue de droit sanitaire et social, 810-818

Vincent, C. (2019). Collective bargaining in France: from hesitant decentralized bargaining to a rush towards prioritizing enterprise level. In T. Müller, K. Vandaele \& J. Waddington (Eds.), Collective bargaining in Europe: towards and endgame (pp. 217-238). Brussels: European Trade Unions Institute (ETUI),

Yerkes, M., \& Tijdens, K. (2010). Social risk protection in collective agreements: Evidence from the Netherlands. European Journal of Industrial Relations, 16(4), 369-383.

Zemmour, M. (2013). Les dépenses socio-fiscales ayant trait à la protection sociale : état des lieux, Publication web sérielle, LIEPP Policy Paper, 2. Paris : Laboratoire Interdisciplinaire d'Evaluation des Politiques Publiques (LIEPP).

Zemmour, M. (2015). Exonérations, exemptions et dépenses fiscales: quels coûts pour la protection sociale?. La Revue de l'IRES, 87, 3-34. 